وراثت صفات زراعى و فيزيولوزيك در نتاج حاصل از تلاقى ارقام گندم نان مغانس و ارگ تحت شرايط تنش كمبود آب

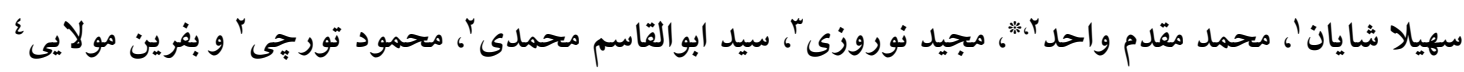

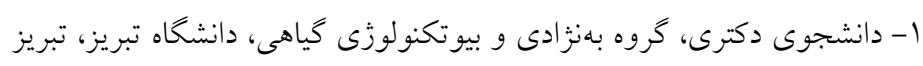

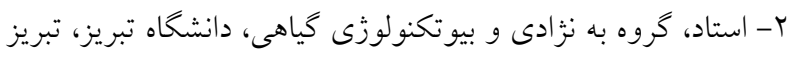

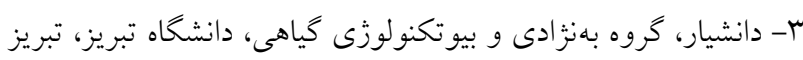

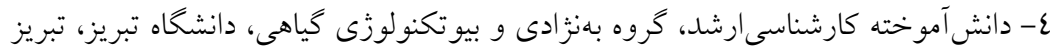

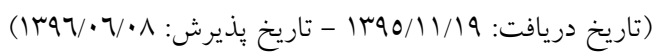

جكيده

تنش خشكى از عوامل كاهش دهنده عملكرد در سطح جهان محسوب مىشود. با توجه به اينكه كُندم بيشتر در نواحى نيمه خشى كشت مى شود، امروزه توجه زيادى به ايجاد ارقام متحمل به تنش خشكى معطوف شده است. در اين يزوهش نحوه وراثت برخى از صفات زراعى و فيزيويولوزيكى در نسلهاى مختلف حاصل از تلاقى دو رقم ارگ (والد متحمل به خشكى) و مغان r (والد حساس به خشكى) در شرايط مزرعه از طريق تجزيه ميانخين نسلها در مزرعه تحقيقاتى دانشكده كشاورزى

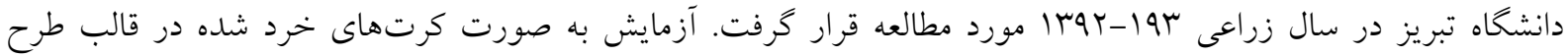

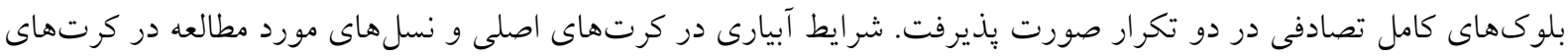

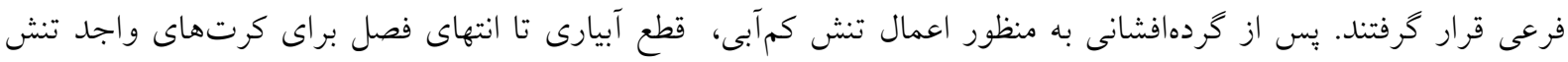

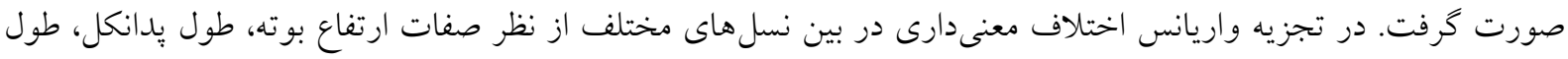

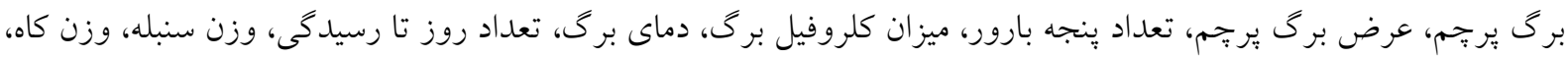

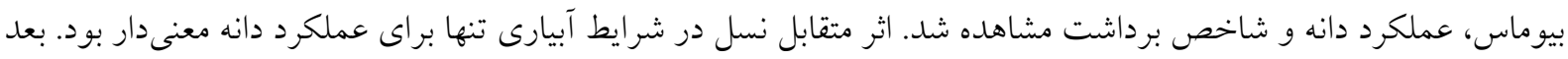

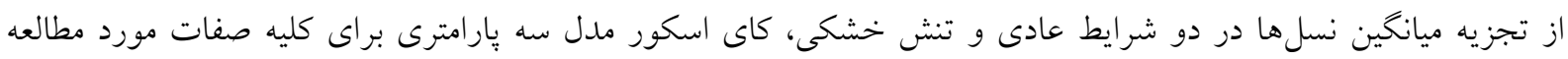

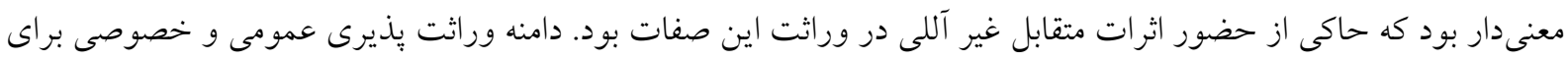

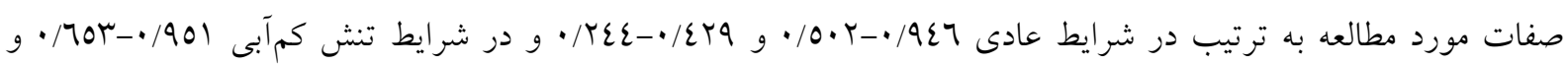

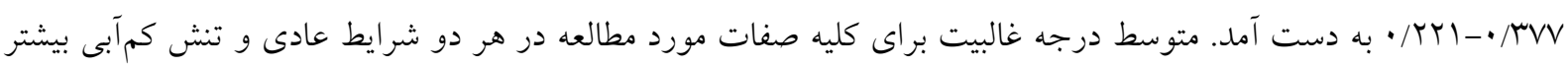

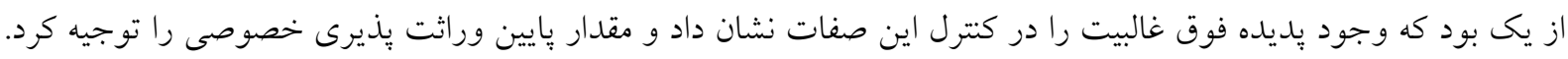

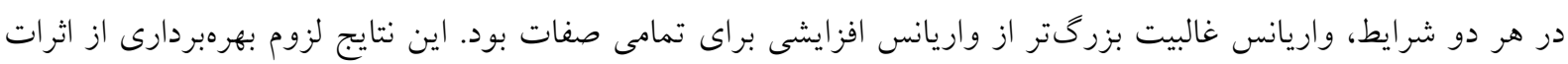

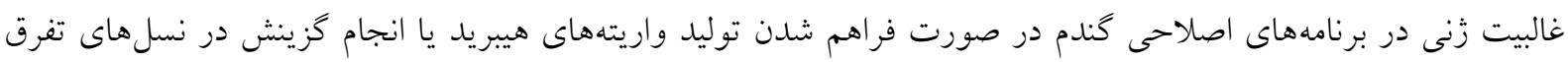

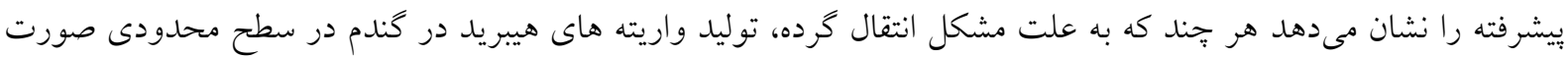

وازگًان كليدى: تجزيه ميانگين نسلها، تنش خشكى، گندم، وراثت يذّيرى

" نويسنده مسئول، آدرس بـت الكترونيكى: mmoghaddam@tabrizu.ac.ir 


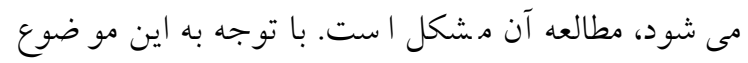

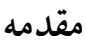

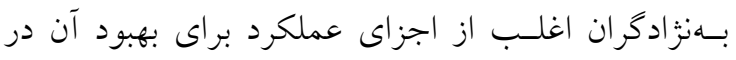
ز سل هاى در حال تفرق ا ستفاده مى كنند. معمولا اين اجزا

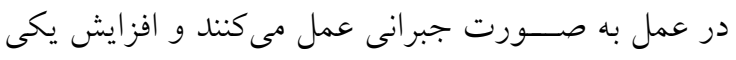

كاهش ديخرى را در بردارد (Munir et al., 2007).

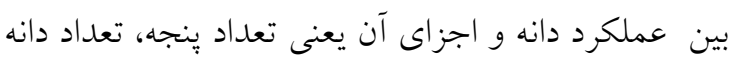

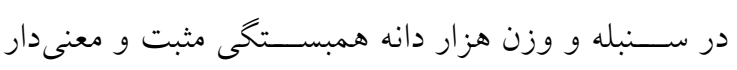
كزارش شده است ) 2015). در ارتباط با صفت سطح برى ير جيم و تأثير آن بر

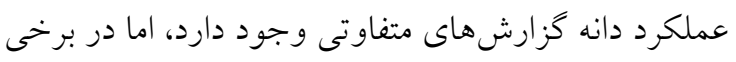

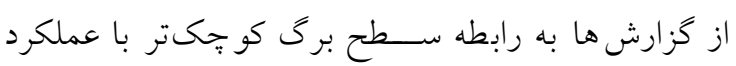

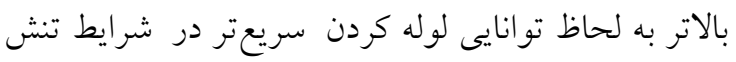
خشكى اشاره شده است (Amawate and Behl, 1995). از طرف ديخر در برخى مطالعات سطح برى ير تمبم بي شتر

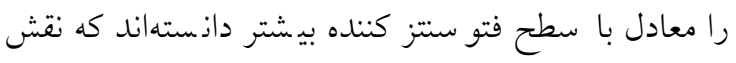

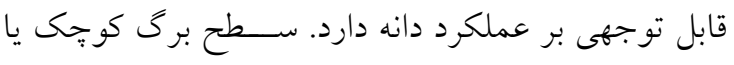

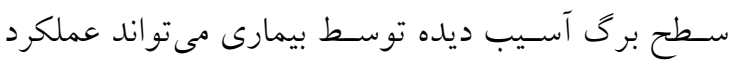

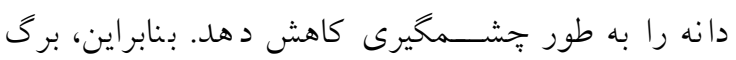

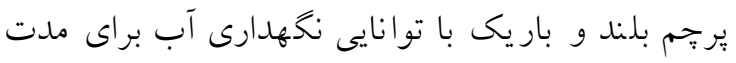

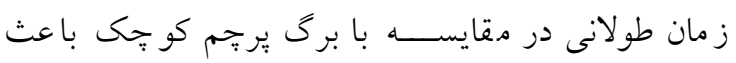

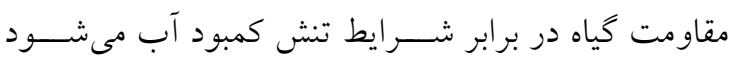

.(Munir et al., 2007 ; Uddin et al., 2015)

انتخاب روش اصـلاحى مناسـب براى بهرهبردارى بهتر از ظرفيت زنتيكى صفات مختلف زراعى در يك كياه بستخى به نوع عمل زنهاى كنترل كننده يك صفت و نحوه ورواثت

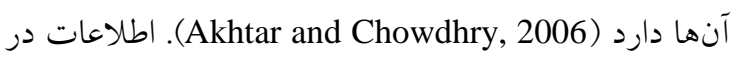

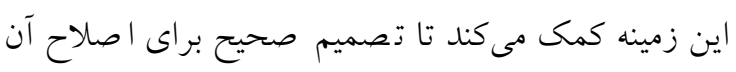

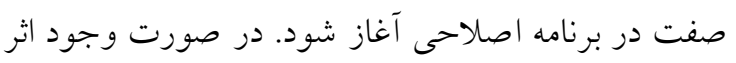
غالبيت و برخى از اشــكال إيســـازى، توليد واريتههاى

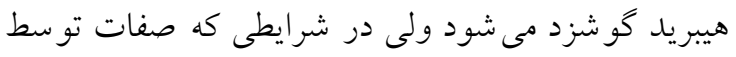

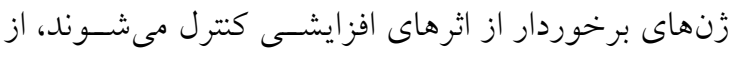
لاين هاى خاص به عنوان واريته زراعى اســتفاده مى كنند.

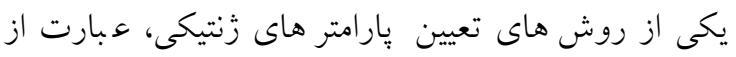
تجزيه ميانخين نسل ها است (Mather and Jinks, 1982). تنش خشــكى يكى از بيجيديدهرين تنش هاى غيرزنده در

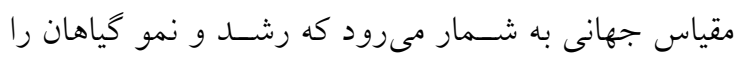
تحت تأثير قرار مىدهد. عوامل ايجاد شــرايط تنش، تعادل

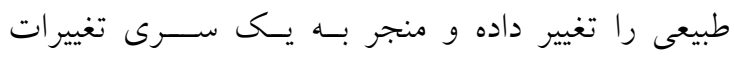

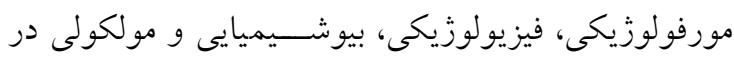

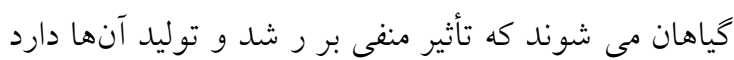

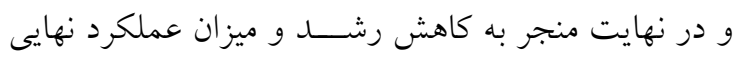

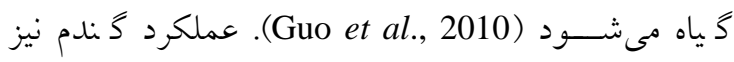
حداقل در •7 ميليون هكتار از زمين هاى كشــــورهاى درد

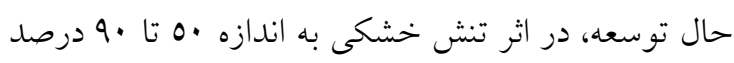

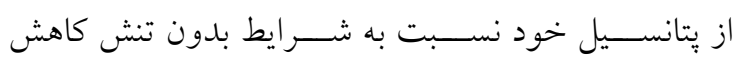

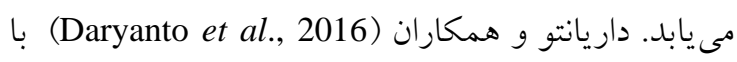

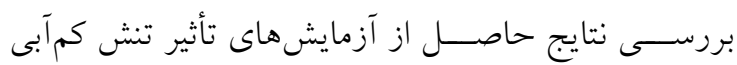

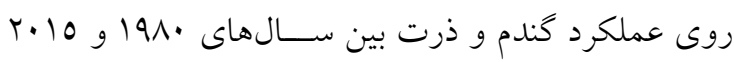

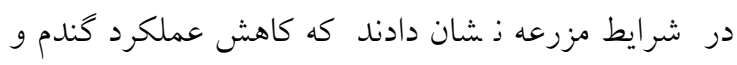
ذرت بسته به كونهها متفاوت اسـت. آنان كاهش عملكرد

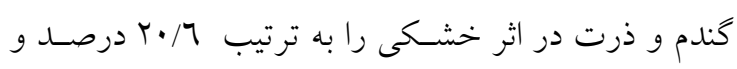

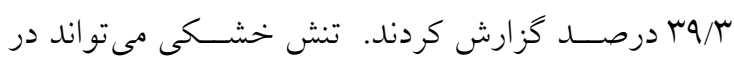

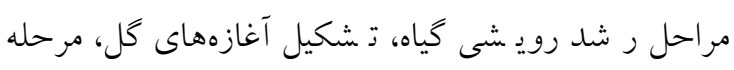

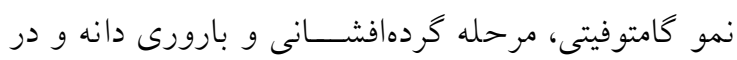

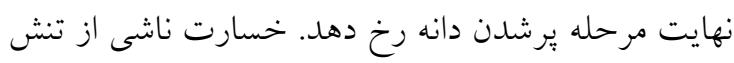

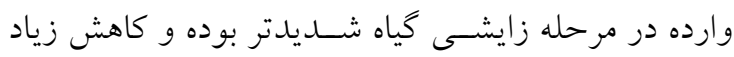

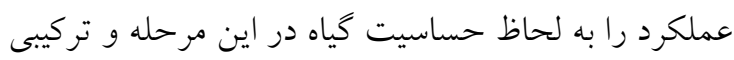
از عوامل مانند كاهش رطوبت خاك و تبخير و تعرق بالا

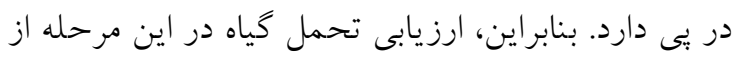
رشد، از اهميت بيشترى برخوردار است (Blum, 1998).

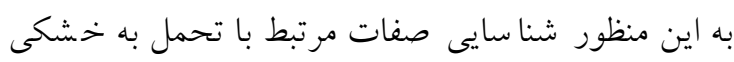
و نحوه كنترل زنتيكى اين صــفنات مى توا ند در كزينش

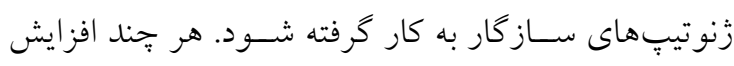

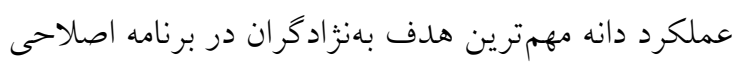

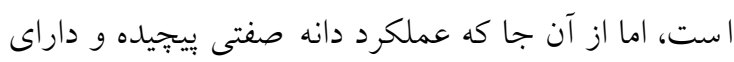

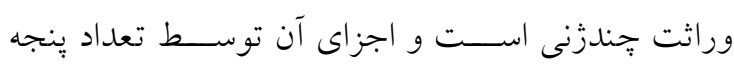

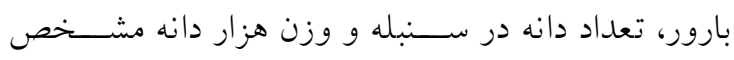


و نيز اثر اييسـتازى در وراثت صـفات فيزيولوزيكى در هر دو شــرايط عادى و كمبود آب نقش دارد. يرا كاش و همكاران (Prakash et al., 2006) با اســفاده از روش

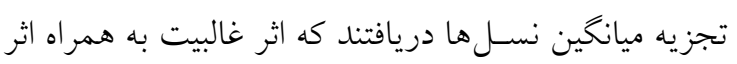
افزايشـى، اثر متقابل افزايشـى × غالبيت و اثر متقابل

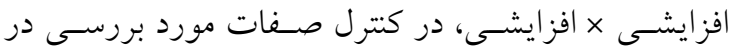
كنام نقش ايفا مى كند. سلطان و همكاران ( ) Sultan et al., 2011) در جههار تلاقى گثندم نان با اســـفاده از تجز يه ميانكين نسـلها، وجود اثرات اييسـتازى را براى صـفات تعداد دانه در سنبله، عملكرد دانه در بوته و وزن صد دانه كزارش كردند. آنها هم:جنين بيان كردند كه مدل ســاده افزايشى و غالبيت براى توجيه وراثت كليه صفات در همه Khattab et al., ) تلاقى ها كافى نيست. خطاب و همكاران 2010) در مطالعه سه تلاقى گندم نان با ا ستفاده از تجزيه

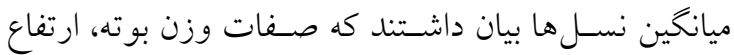
بوته، عملكرد دانه در بوته و تعداد دانه در سنبله به و سيله اثرات افزايشــى، غالبيت و نيز اثرات اييسـتازى كتترل

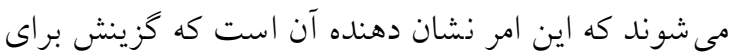
اين صـفات در نسـلـهاى در حال تفرق با افزايش ميزان هوموزيخوتى مؤثرتر خواهـــ بود. عـابــى و همكــاران (Abedi et al., 2015)

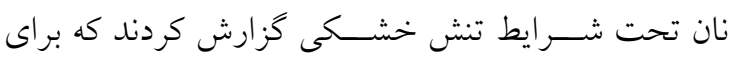
صفات تعداد ينجه، وزن سنبله اصلى، عملكرد دانه و تعداد

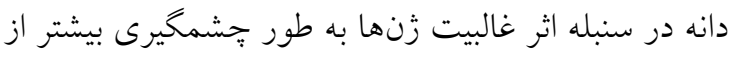

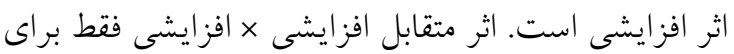
صفات شاخص برداشت، وزن سنبله، تعداد دانه در سنبله و وزن دانه در سنبله اصلى گزارش شد. جلويى و همكاران (Cheloei et al., 2012)

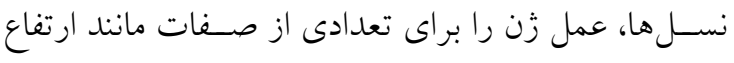
كَياه، طول يدانكل، طول ســنبله، تعداد دانه در ســنبله، عملكرد دانه در بوته، وزن هزار دانه، تاريخ گلدهى و وزن بوته در دو تلاقى گندم مورد بررسى قرار دادند. اثر غالبيت زنها مهمترين عامل زنتيكى در كنترل بيشتر صفات مورد بررسى شناخته شد. همجنين اييستازى افزايشى × افزايشى
در اين روش، علاوه بر اثرهاى افزاي شى و غالبيت، برآورد

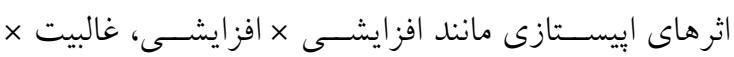
غالبيت و افزايشى × غالبيت نيز امكانيذير است ( Singh

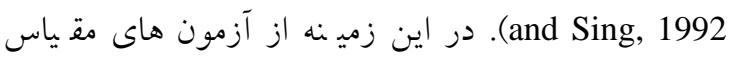
براى ت شخيص وجود اين اثرها ا ستفاده (Scaling Tests)

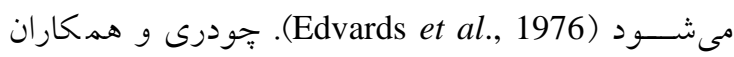
نيز نشـــان دادند كه آزمون (Chowdhry et al., 1999)

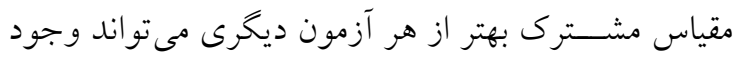
اييسـتازى زن را تاييد كند. بر اســاس اركول و همكاران براى صـفات وزن دانه و تعداد دانه (Erkul et al., 2010)

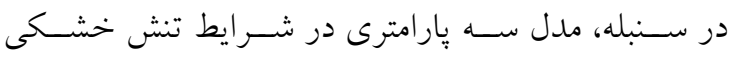
وراثت اين صفات را در كندم بر عهده دا شت. ع شقى و هم كاران (Eshghi et al., 2010) گزارش كردند كه اثر غالبيت زنى در گَندم در كتترل عملكرد دانه و تعداد دانه Sheikh et al., ) در سنبله مؤثرتر است. شيخ و همكاران

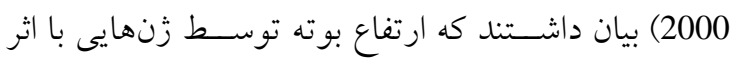

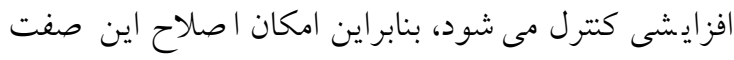

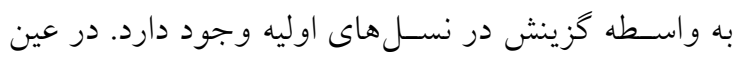

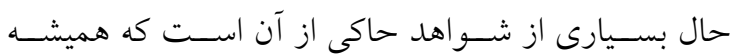

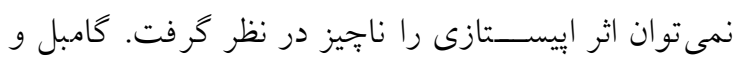
بورى (Gamble and Burke, 1984) با اسـتفاده از تجزيه ميانخين نسـل ها و آزمون مقياس مشـترك، صـفاتى مانند

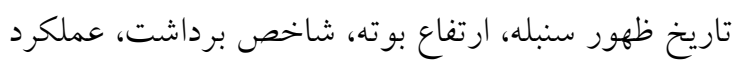

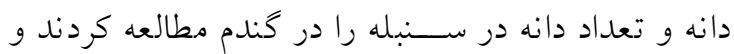

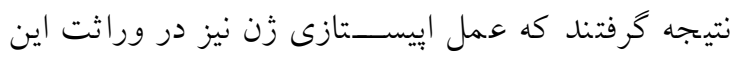
صـات دات دا لت دارد. اختر و جودرى ( Akhtar and CP1 به كمك تجزيه ميانخين ذنسل های (Chowdhry, 2006 در كندم مشــاهده كردند كه اثر BC اييستازى، نقش مهمى در كنترل صفات ارتفاع بوته، تعداد دانه در ســنبله، سـطح برى يرجّم و وزن هزار دانه دارد. اسـدى و همكاران (Asadi et al., 2015) در مطالعهاى كه تهن روى هفت جمعيت از گندم انجام دادند از طريق تجزيه ميانخين نسـل ها به اين نتيجه رسـيدند كه نوع اثر زنهاى دخيل در كنترل اكثر صفات به شرايط آبيارى بستخى دارد 
هدف از اجراى اين تحقيق، برآورد اثرها و وار يانس هاى

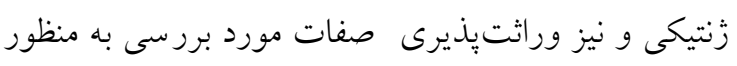
تعيين راهبرد اصلاحى در دو شرايط عادى و تنش كمبود وردي آب بود.

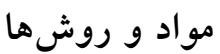
مواد كياهى و مـ شخ صات طرح آزماي شى: مواد كياهى

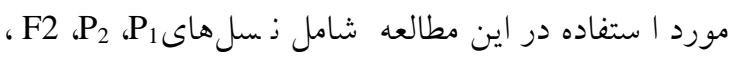
حاصـل از تلاقى رقم ارگ به عنوان و الد اول و متحمل به تنش خشكى و رقم مغان مَ به عنوان

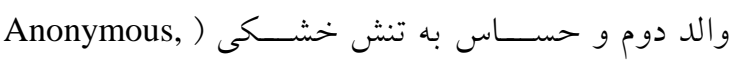
2013) بودند. بذرهاى والدين از مؤسسه تحقيقات اصلاح

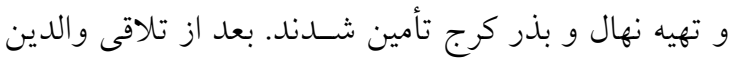
و توليد نسل هاى مورد نظر در ايستخاه تحقيقاتى دانشكده نهاه

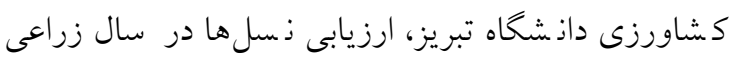

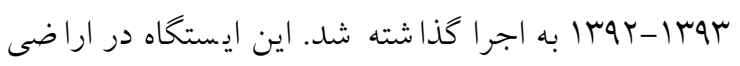
كركج با IV دقيقه و Iا در جه طول جغر افيايى و 0 دقيقه

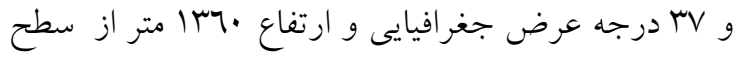

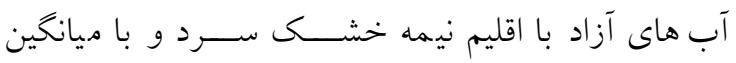
بارندگى TVO ميلىمتر، واقع شده ا ست. به دليل كم بودن بذر نسل F1 و لزوم توليد نسل F2، اين نسل در مزرعه به

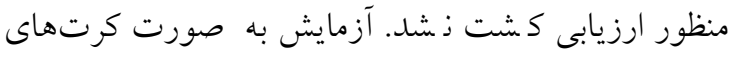
خرد شده بر بايه بلوكهاى كامل تصادفى بادو تكرار در

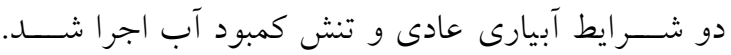

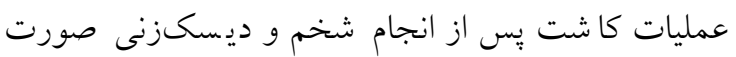

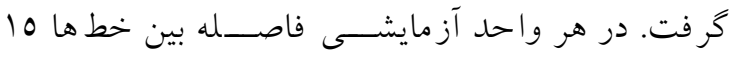

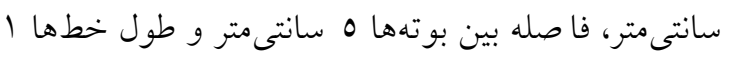

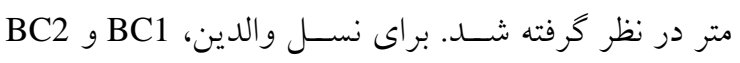

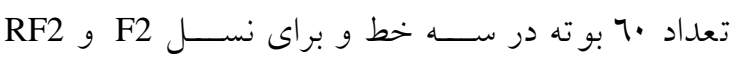

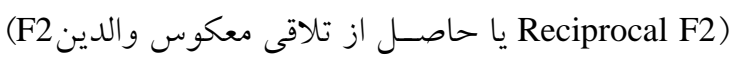

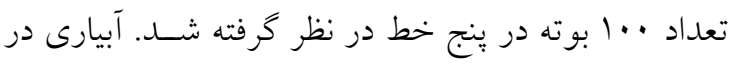

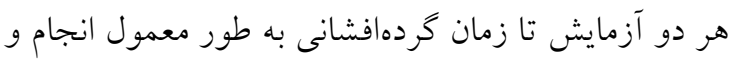

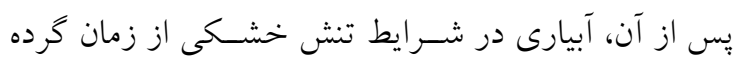

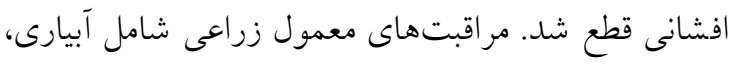

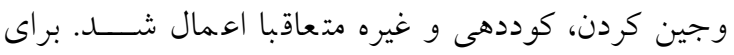

اهميت بيشــترى نســبت به إييسـتازى غالبيت × غالبيت

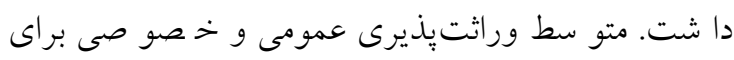

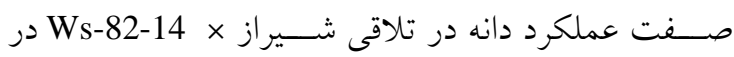

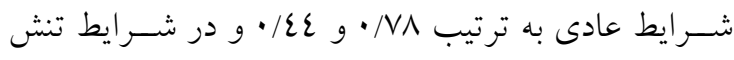

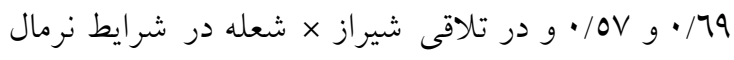

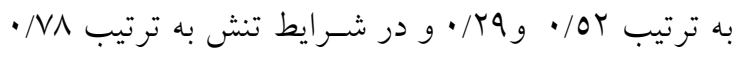
و 107 • به د ست آمد. آنان عنوان كردند كه متو سط درجه غالبيت زنى نيز در اكثر صــفات مورد ارزيابى بزرگتر از

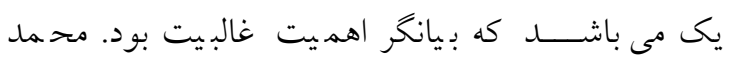
(Mohamed, 2014) ا ستفاده از شش ذسل بايه حاصل از تلاقى Sakha 94 Tokwie به به بنوان تلاقى اول و 168 Tokwie

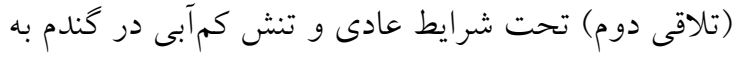

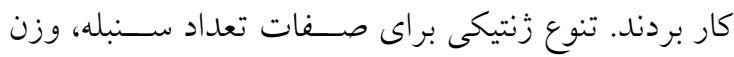

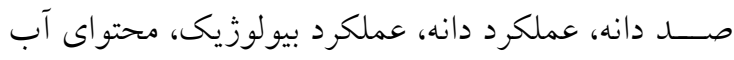
نســى و ميزان كلروفيل در هر دو تلاقى و دو شـــــايط آبيارى مشاهده شد. در دو تلاقى و دو شرايط آبيارى، فوق

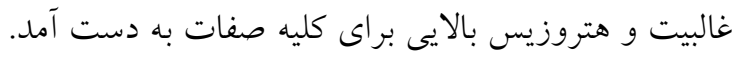

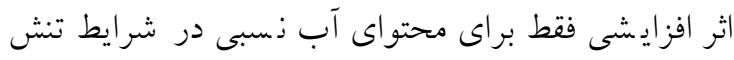

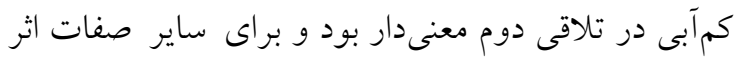

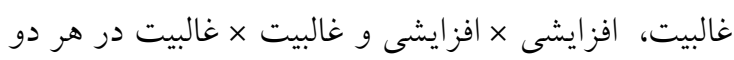

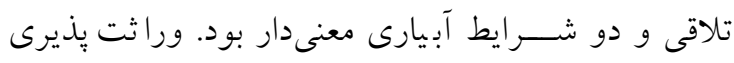

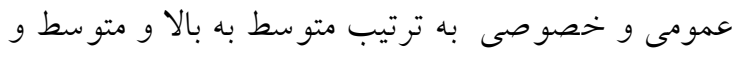

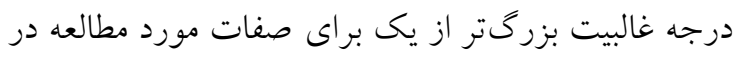

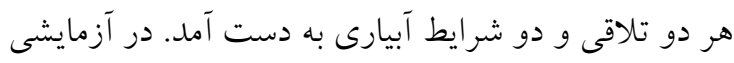

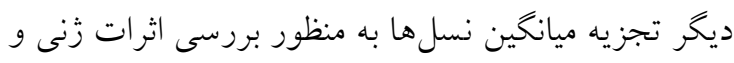

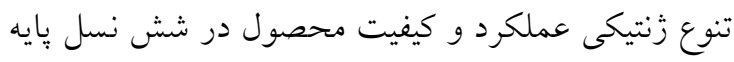

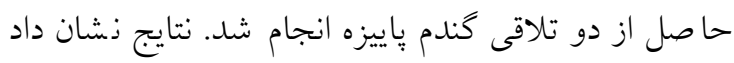

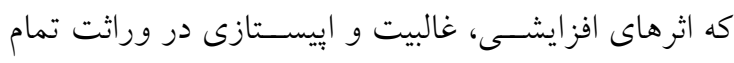
صفات مورد مطالعه دخالت دارد. مدل سه بارامترى براى توجيه زنتيكى اكثر صفات كافى نبود. براى بي شتر صفات بـات

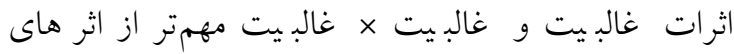
افزايشى و انواع ديخر اييستازى بود (Bilgin et al., 2016). 
1982) اذجام گر فت كه علت آن تفاوت نوع اثرهاى زن براى هر صفت در دو محيط بود. در تجزيه ميانكين نسلها

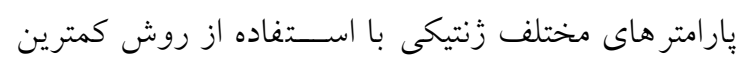

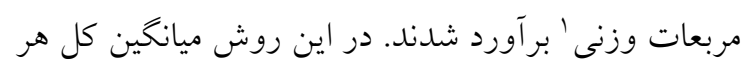
صفت به صورت زير نشان داده مىشود: $\mathrm{Y}=\mathrm{m}+\alpha[\mathrm{d}]+\beta[\mathrm{h}]+\alpha^{2}[\mathrm{i}]+2 \alpha \beta[\mathrm{j}]+\beta^{2}[\mathrm{l}]$ رابطه (1)

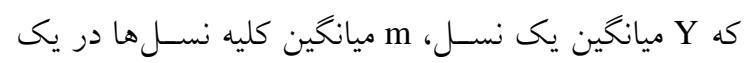

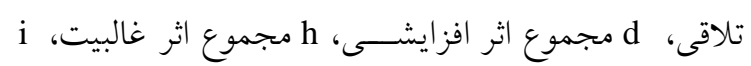

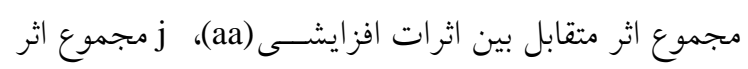

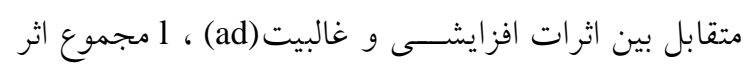

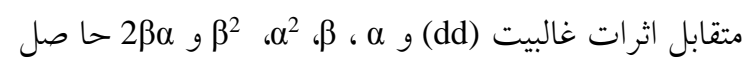

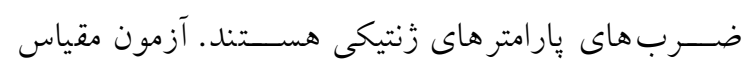

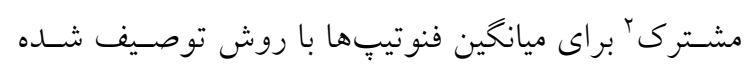

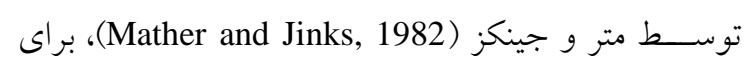
تعيين مناسبترين مدل زنتيكى در شرايط كم آبى و عادى

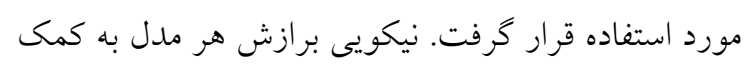

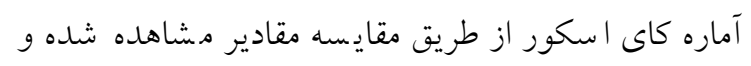

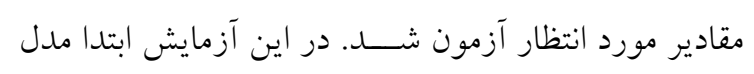

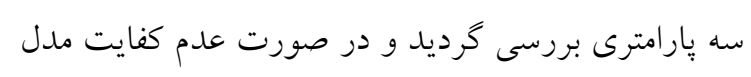

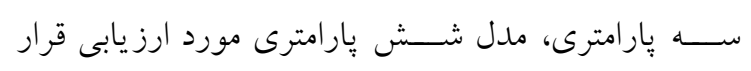

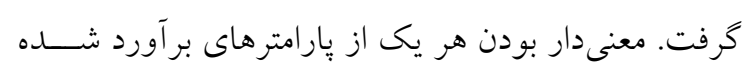

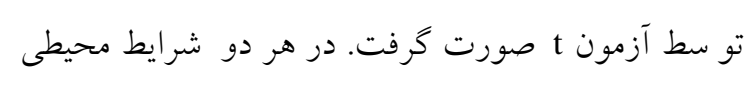

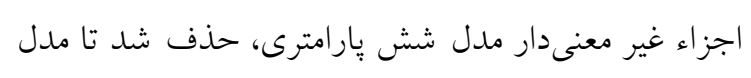

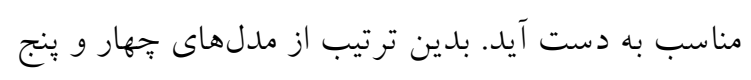
بارامترى، در تبيين ميانخين هاى مشاهده شده استفاده شد.

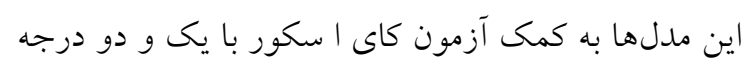

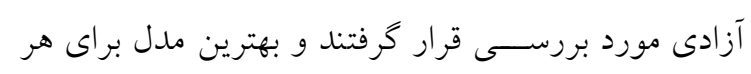

يك از صفات مشخص شد.

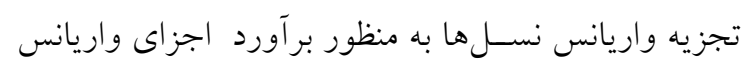

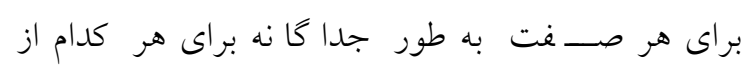

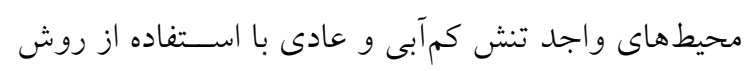

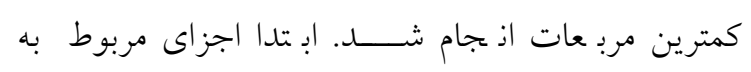

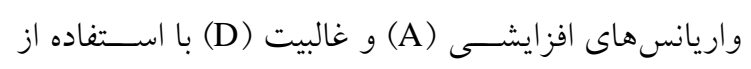

1- Weighted least squares

2- Joint Scaling Test
جلو گيرى از خسارت ناشى از يرندگان توركشى سراسرى

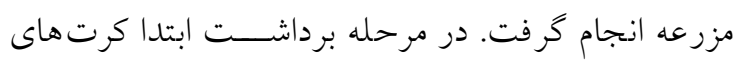

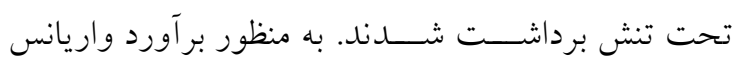

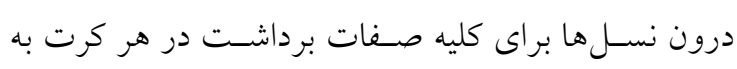

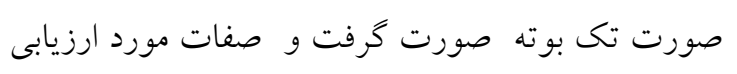

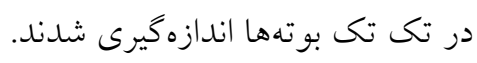

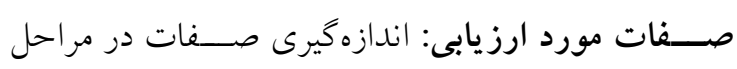
مختلف رشــ صـورت كرفت. دماى برى، ميزان كلروفيل

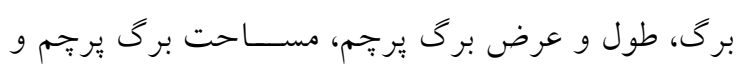

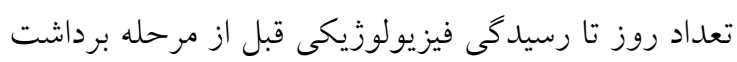

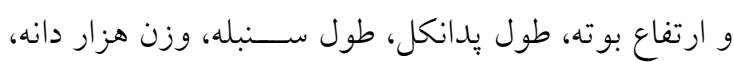

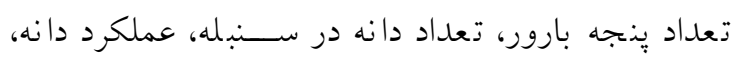

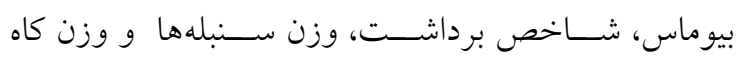

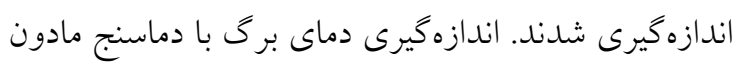

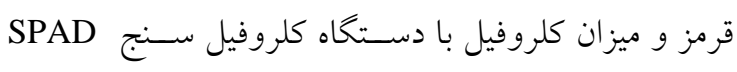
براى تمام بو ته ها اذجام شـــــــ (James et al., 2002)

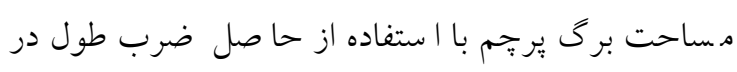

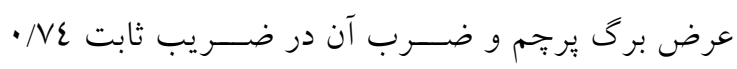
بر آورد شد (Muller, 1991). تجزيه و تحليل آمارى: قبل از تجزيه واريانس، صــادق بودن فرضهاى تجزيه واريانس شامل نرمال بودن دادهها،

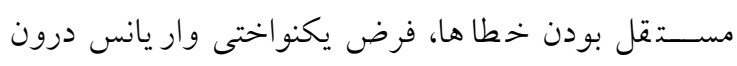
تيمارها و توزيع تصادفى خطاهاى آزماي شى با ا ستفاده از

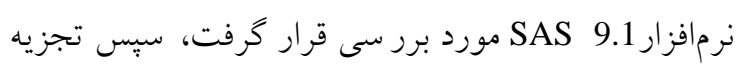

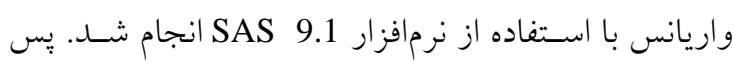
از تجزيه واريانس، در صسورت وجود تفاوت معنىدار بين

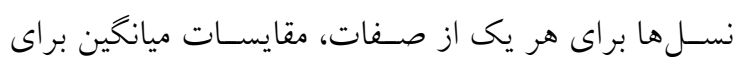

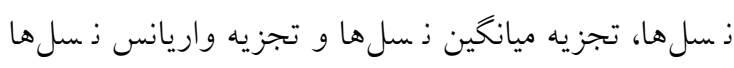
براى هر صفت انجام يذيرفت. تجزيه ميانخين نسلها و تجزيه واريانس نسلهام ندائ در اين

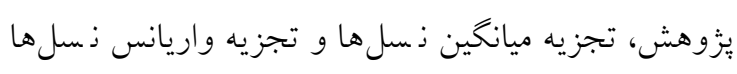

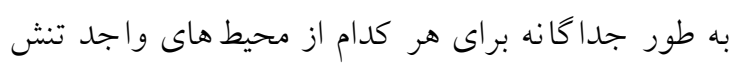

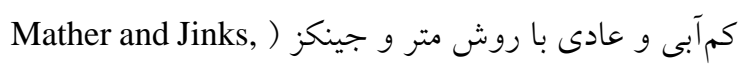


براى كليه صسـفات به جز عملكرد دانه در واحد ســطح

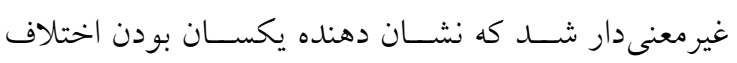

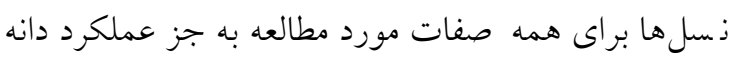
در هر دو شرايط عادى و تنش كم آبى است. ميانخين زسل هاى مختلف براى صفات مورد مطالعه تحت

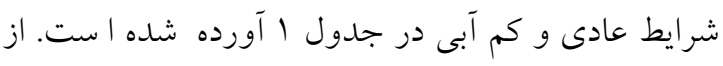

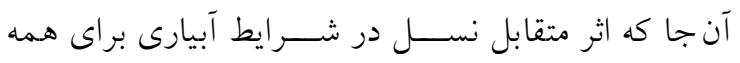

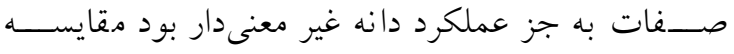

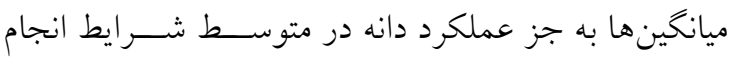
كرفت. بر اساس نتايج مقايسه ميانخينها، والد P2 (مغانس)

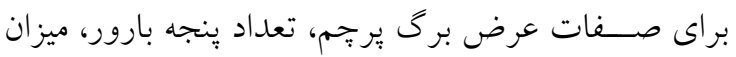

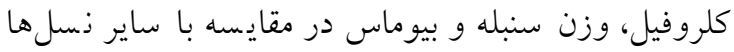

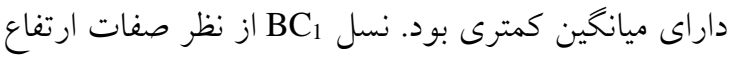
بوته، طول برك ير تم، تعلداد ينجه بارور، وزن سنبله، وزن كاه و بيوماس نسبت به ساير نسل ها ميانخين بالايى داشت.

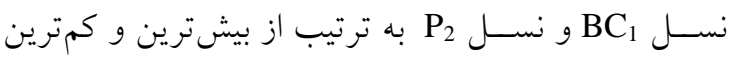
عملكرد دا نه در دو شـــايط عادى و تنش كمبود آب لب ترئ

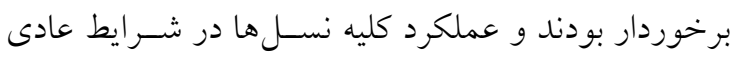

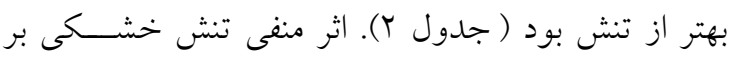

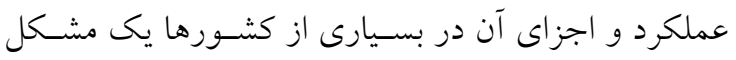

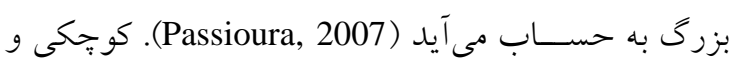

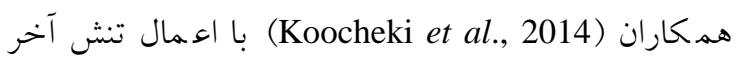

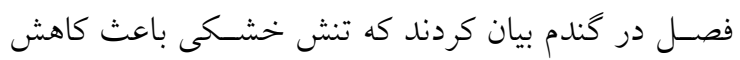
تعداد دانه در ســـبله، وزن هزار دانه، بيوماس و و عملكرد دهرد دانه مى شود. مومنى و همكاران (Moemeni et al., 2008)

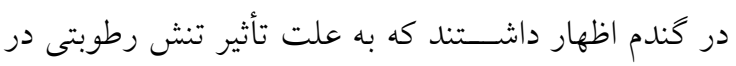
اوايل ظهور ســنبله با توجه به شـــت تنش، تعدادى از

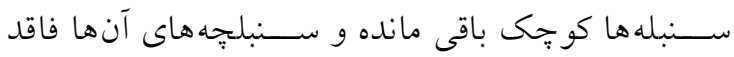
كلجهههاى بارور است و اين امر سبب كاهش تعداد سنبله بارور مى شود. به هر صورت، استفاده از ارقامى با ظرفيت بالاى عملكرد در شـــر ايط تنش هاى رطوبتى متوســــ و

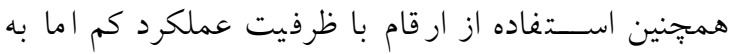
مقاوم به خشكى، در شرايط تنشهاى شديد رطوبتى، مورد توافق يثزوهشخران است (Mohammadi et al., 2010).
روش حداقل مربعات محاسـبه شــندن و ســبس واريانس

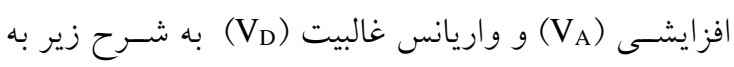

دست آمد (Mather and Jinks, 1982).

$$
\begin{array}{ll}
\mathrm{V}_{\mathrm{A}}=\frac{\mathrm{A}}{2} & \text { رابطه (T) رابطه (r) } \\
\mathrm{V}_{\mathrm{D}}=\frac{\mathrm{D}}{4} & \text { (T) }
\end{array}
$$

واريانس محيطى (VE) و مقادير وراثتيذيرى عمومى

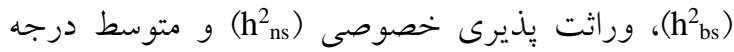
غالبيت (ā) با استفاده از واريانسهاى برآورد شده در واحد ميانخين و مطابق فرمولهاى زير برآورد شدند كه در آنها

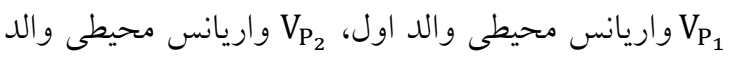
دوم، r تعداد تكرار و V واريانس زنتيكى بود.

$$
\begin{aligned}
& V_{E}=\sqrt{V_{P_{1}} \times V_{P_{2}}} \quad \text { (₹) }
\end{aligned}
$$

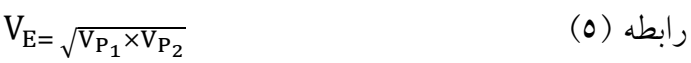

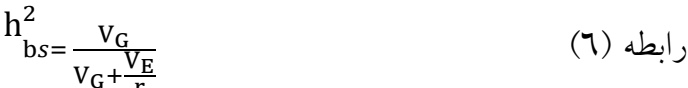

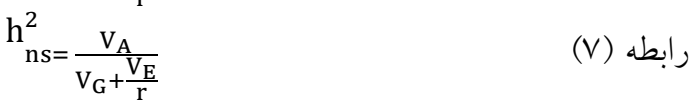

$$
\begin{aligned}
& \overline{\mathrm{a}}=\sqrt{\frac{2 \mathrm{~V}_{\mathrm{D}}}{\mathrm{V}_{\mathrm{A}}}} \quad \text { (ᄉ) }
\end{aligned}
$$

\section{نتايج و بحث}

نتايج آزمون نر مال بودن خطا ها و يكنواختى وار يانس

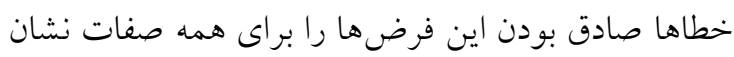

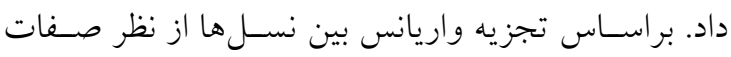

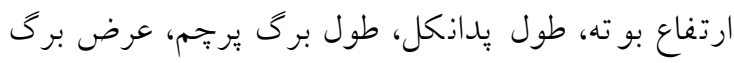

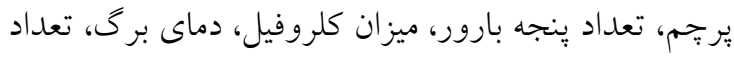

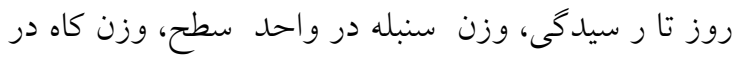

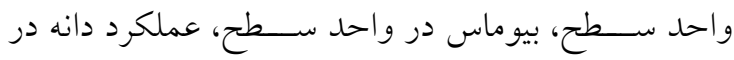

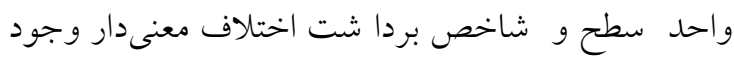

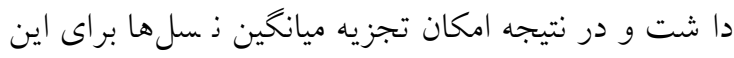

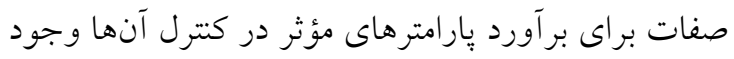
دا شت. در اثر تنش كليه صفات مورد مطالعه به جز دماى برى كاهش يافتند، ولى اين كاهش به غير از طول ســنبله

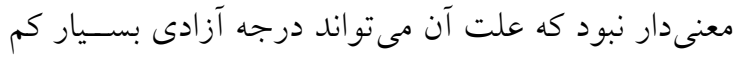
براى شرايط آبيارى با شد. اثر متقابل ذ سل × شرايط آبى 
والدى كه داراى ميانخين بالاترى اسـت رخخ داده اسـت و

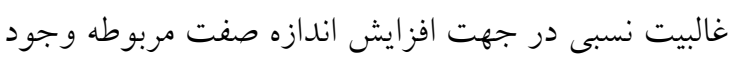

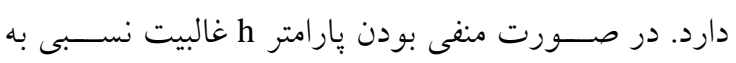

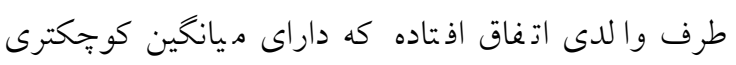

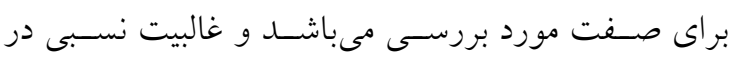

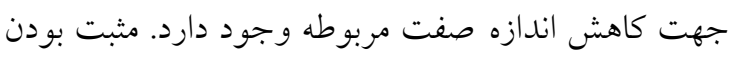
يارامتر (d) به معنى برترى والد غالب در كنترل صـفنت

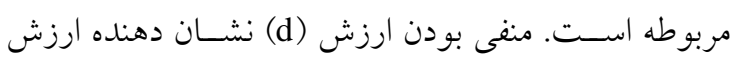

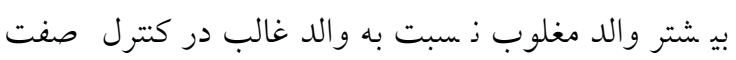
اســت. همجنين علامت مخحالف [d] و [i] نشـــاندهنده

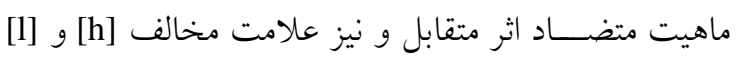

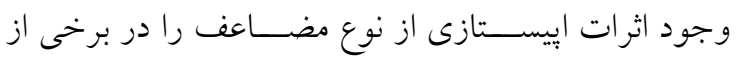

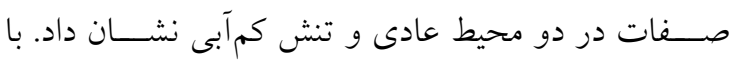

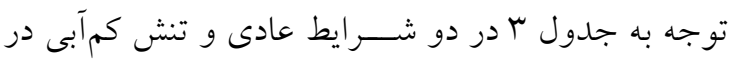
برخى از صفات هر دو نوع إيستازى افزايشى در افزايشى دونى

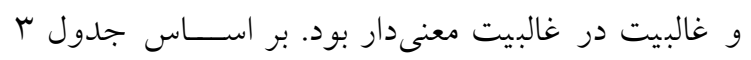
معنىدار نشدن [j] در برخى از صفات مورد مطالعه ممكن

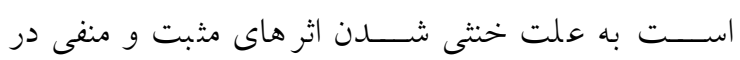

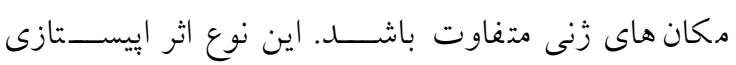

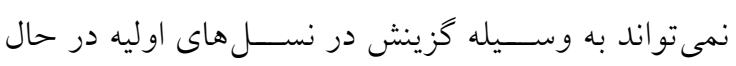
تفرق تثبيت شود.

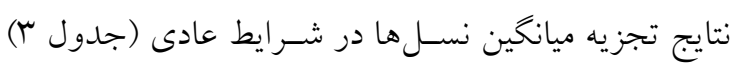

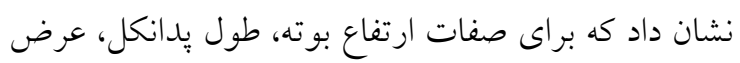

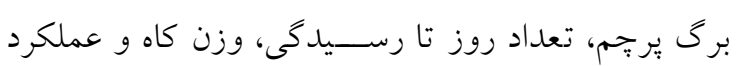

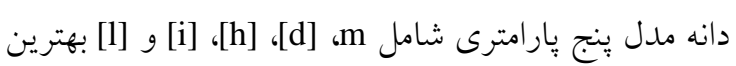
برازش را داشتند. آماره كاى اسكور براى صفات وزن كاه بـاه

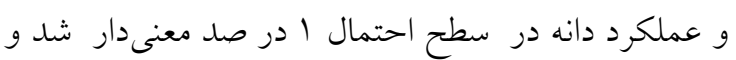

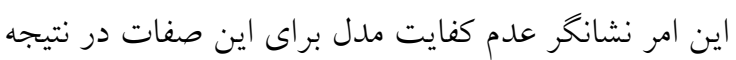

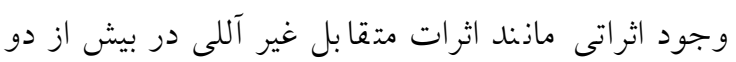

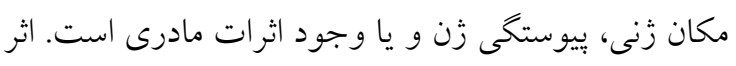

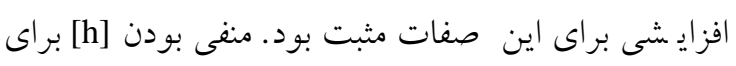

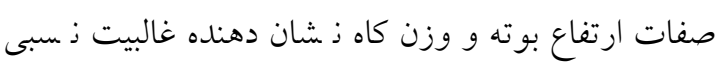
در جهت كاهش اين صــفات در اين تلاقى اســت. براى

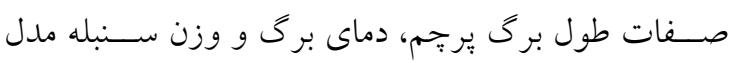

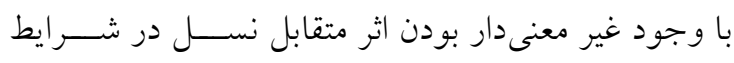

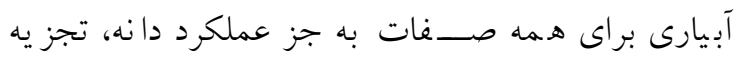

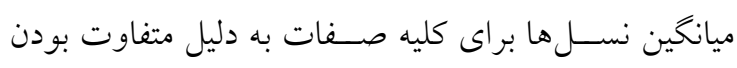

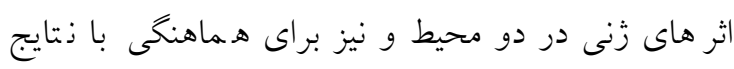

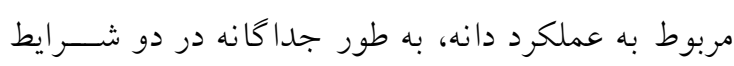

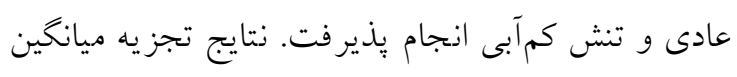

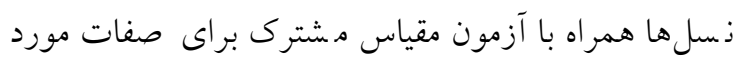

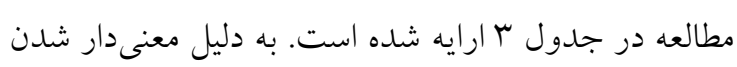

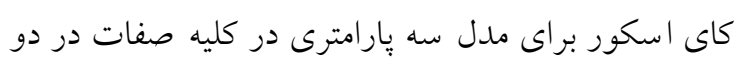

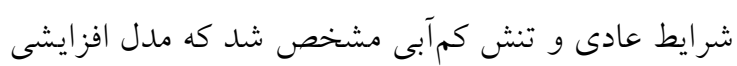

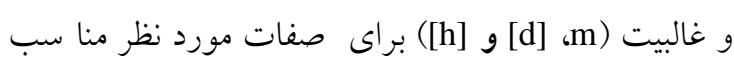

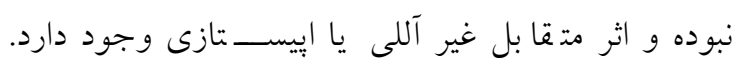

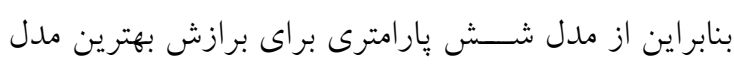

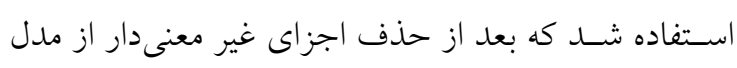
شش يارامترى بهترين مدل براى هر صفت در هر كدام از

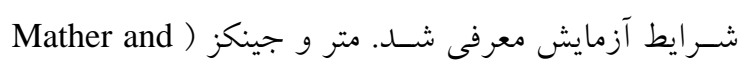

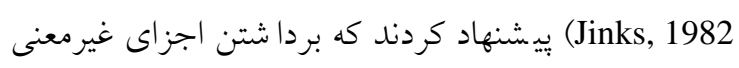

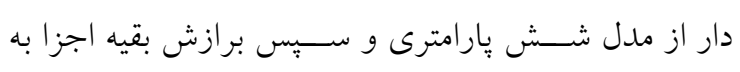

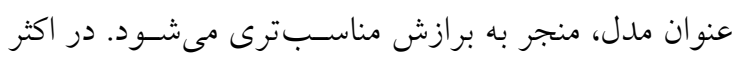

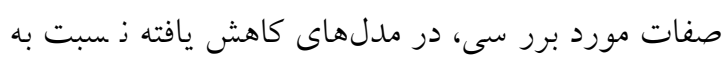

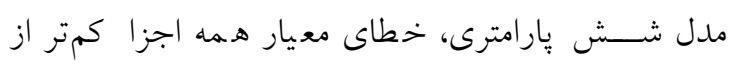

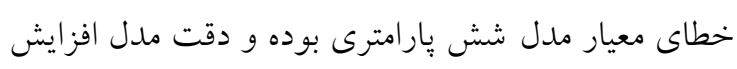

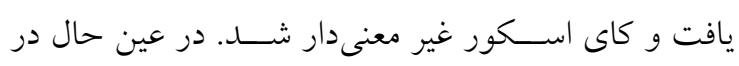

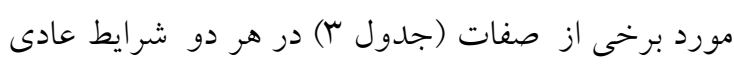

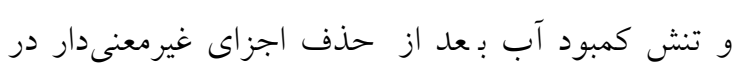
مدل شش يارامترى، مقدار كاى اسكور هنوز معنى دار بود.

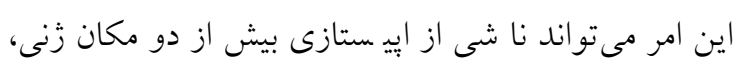
يبيوستخى زنى يا هر دو باشد (Mather and Jinks, 1982).

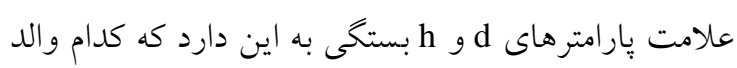

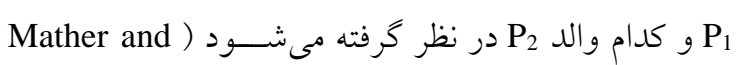

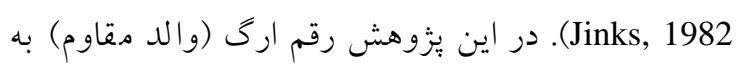

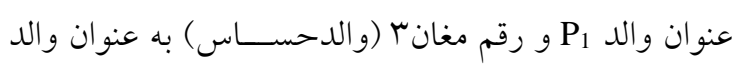

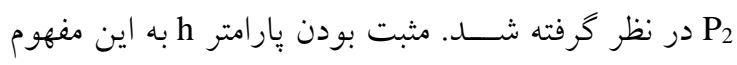

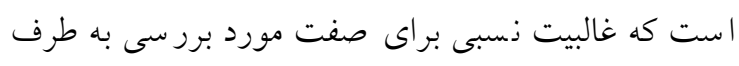


كنترل مى كنند، بلكه در نتيجه افزايش تعداد زنهاى كنترل كننده صــفات، تعداد عواملى كه با هم اثر متقابل دارند

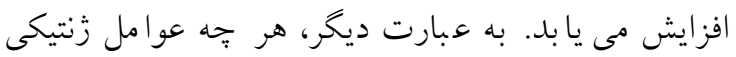
كتترل كننده صــفات، افزايش مى يابند اثرهاى متقابل بين آنها نيز افزايش مىيابد. در كليه صفات مورد مطالعه سهم اثر غالبيت [h] بيشتر از اثر افزايشسى [d] در دو شــــــ عادى و تنش كمبود آب بود و بيشتر بودن اثر غالبيت نسـبت به اثر افزايشسى اهميت بيشتر اين اثر را در كنترل اين صـفات نشـان داد. اين امر توليد واريتههاى هيبريد را در اصـلاح اين صـفات، در صـورت رفع موانع توليد اين واريته ها، بيان مىدارد. وجود تفاوت ها در برآوردهاى حاصل از دو محيط، تأثير محيط بر نوع واكنش زنها را رابه اثبات مىرساند. بنابر اين اصلاح براى هر محيط بهتر است در شــايط ويزه هـمان محيط انجام گيرد تا بازده كار افزايش يابد. اختر و جودرى ( Akhtar and Chowdhry, 2006)، خطـاب و همكــاران (Khattab et al., 2010)، ســلطان و همكاران (Sultan et al., 2011) و عابدى و همكاران (Abedi et al., 2015) نيز نشــان دادند كه عمل اييسـتازى زن در كترل عملكرد دا نه و اجزاى عملكرد

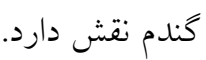
در تجزيه ميانخين نســل ها اثرهاى افزايشــى و يا اثرهاى متقابل مرتبط با اثر افزايشـى تابعى از درجه يراكندكى زنهاى افزايش دهنده صــفت بين والدين هســتند. در حالى كه اثرهاى غالبيت برآيند جهت غالبيت ' در هر مكان

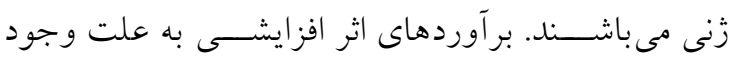
درجه بالايى از بر اكندگى كوجى هستـند. به طور مشـابه اخر غالبيت جهت ارد نباشـــ مقدار آن به علت خنثىشــن اثرهاى متضـاد مكانهاى زنى كوجكى خواهد بود. به طور كلى اثر زنها در جهت هاى مختلف ممكن اســت باعث شـود اثرهاى مربوطه كمتر از مقدار حقيقى بر آورد شـود. در عين حال واريانس زُنتيكى به وســيله اثرهاى متضــاد
جهار يارامترى m، [d]، [d] و [1] برازش خوبى با دادهها

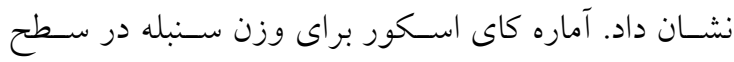
احتمال ا درصد معنى دار شد. اثر افزايشى فقط براى دماى

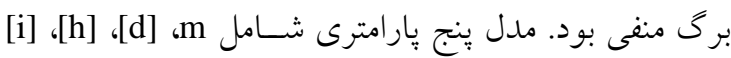

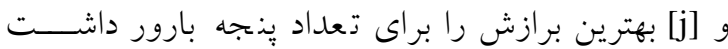

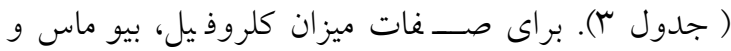
شاخص برداشت مدل جهار بارامترى m، [d]، [h] و [i] از

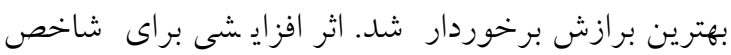

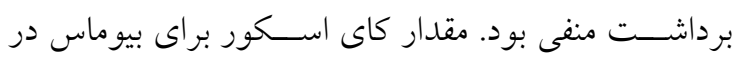

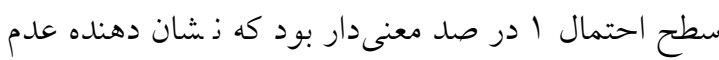

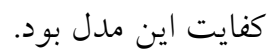

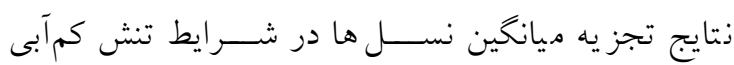

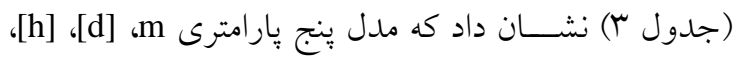

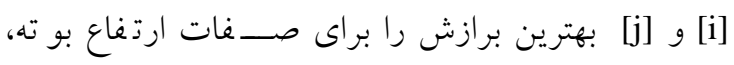

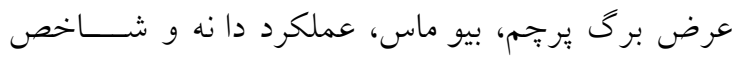
برداشت دارد. مقدار كاى اسكور براى ارتفاع بوته، شاخص لتص برداشــت، بيو ماس و عملكرد دانه در ســطح احتمال 1

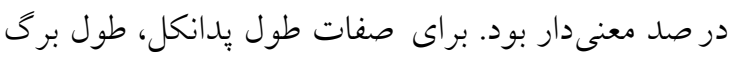
يرجّم، تعلداد يُجه بارور، تعداد روز تا رسـيدگى، وزن

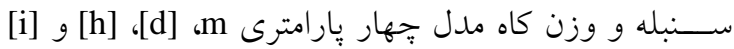
بهترين برازش را دا شت. مقدار كاى اسكور براى صفات وزن سنبله و وزن كاه در سطح احتمال ا در صد معنىدار بود كه مبنى بر عدم كفايت اين مدل اسـتـ اثر افزايشسى

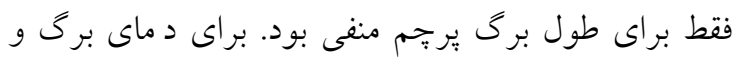
ميزان كلروفيل مدل ينج پֶارامترى m، [d]، [h]، [i] و [1]] برازش خوبى با دادهها نشـــان داد. يّارامتر [d] براى دماى

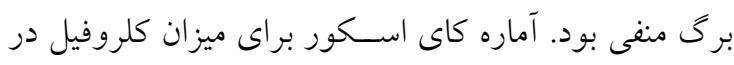

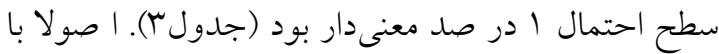
توجه به وجود اثرهاى إييسـتازى و نيز ناكافى بودن مدل افزايشى و غالبيت براى صفات مورد بررسى در دو محيط مى توان بيان كرد كه نه تنها زنهاى بيشترى اين صفات را 
بارور از بيشترين وراثت يذيرى عمومى برخوردار بود. در

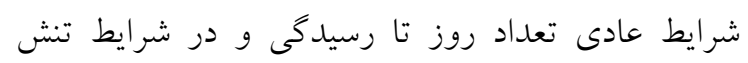
كمبود آب طول برى يرجم از بيشترين وراثتيذيرى

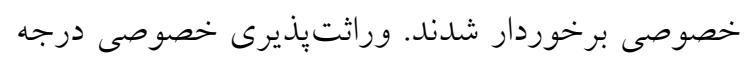
شباهت بين خويشاوندان را نشان مىدهد و در نتيجه بيش ترين اهميت را در برنامه اصلاحى دارد. در حالى كه وراثتوذيرى عمومى بيشتر از لحاظ نظرى حايز اهميت است.

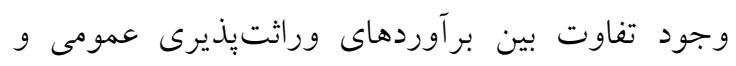
خصوصى در صفات بيانخر سهم بيشتر اثر غالبيت است. اخر بردئ

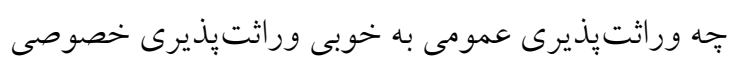

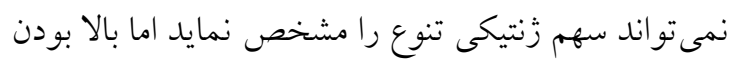

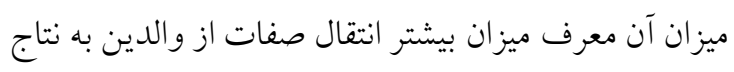
مى باشد. اين نتايج با نتايج حاصل از تحقيقات محمد معرد مطابقت دارد. در عين حال مقدا و (Mohamed, 2014) عبدالرحمان (Magda and Abd EL-Rahman, 2013) هر دو وراثتِيذيرى عمومى و خصوصى را در آزمايش خود متوسط به بالا گزارش كردند. اين عدم تطابق مى تواند به

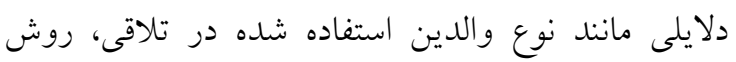
تلاقى و شرايط آزمايش مرتبط باشد. متوسط درجه غالبيت در كليه صفات و هر دو شرايط محيطى بزرگتر از يك بود كه بيانكر اهميت اثر غالبيت

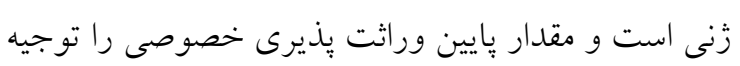

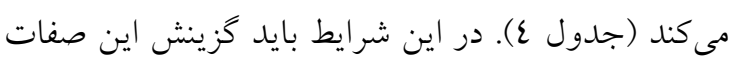

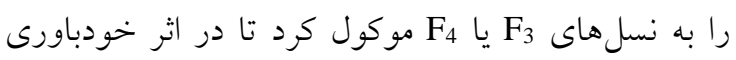

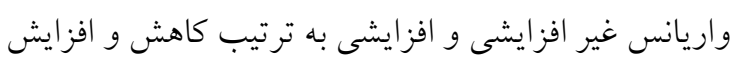

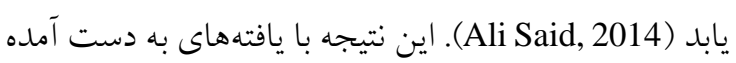

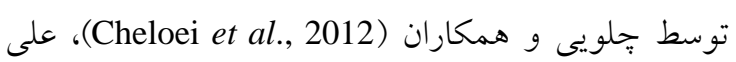
سعيد (Ali Said, 2014) و محمد (Mohamed, 2014) در كندم مطابقت دارد. در حالى كه متوسط درجه غالبيت در اكثر صفات مورد مطالعه گندم، توسط مقدا و عبدالرحمان كمتر از يك (Magda and Abd EL-Rahman, 2013)

$$
\text { كزارش شده است. }
$$

تحـت تـأثير قرار نمى گيرد جهون واريـانس از مجموع مربعات اثرهاى هر مكان زنى به دست مى آيد و بنابر اين به صـورت مجموع تغييرات اثرهاى افزايشسى و غالبيت بيان مىشـــود. از اينرو تجز يه وار يانس نســـل ها مىتواند اطلاعات تكميلى در جوار تجزيه ميانخين نسـلـلها براى تفسـير ســاختار زنتيكى فراهم زمايد، هر خند كه اين

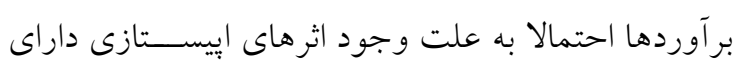
ار يب خواهـند بود. روى (Roy, 2000) اجزاى وار يانس زنتيكى را متأثر از خطاى نمو نهبردارى دانســت و اظهار

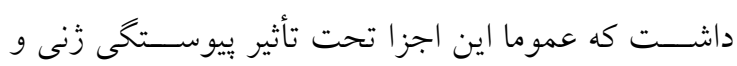

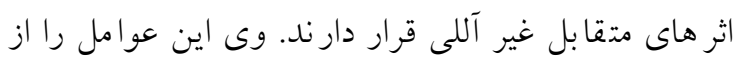
مشكلات اصلى در برآورد دقيق اجزاى واريانس داذست.

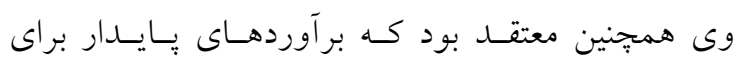
واريانس زنتيكى با خطاى بايين با داشتن نسل هاى كافى و تكرار آزمايش در جنند محيط امكان دارد.

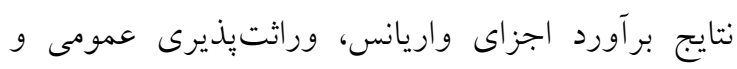
خصوصى و متوسط درجه غالبيت براى هر صفت به كمى برى وردي

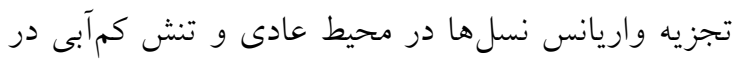

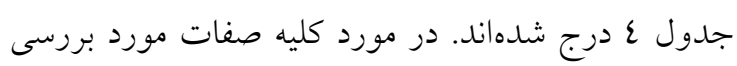
مقدار واريانس افزايشى از واريانس غالبيت در دو محيط عادى و تنش كمبود آب كمتر بود. اين امر نشان مىدهد كه توليد ارقام هيبريد در جهت نيل به اهداف اصلاحى مورد نظر براى صفات مذكور روش مؤثرترى از توليد لاينهاى

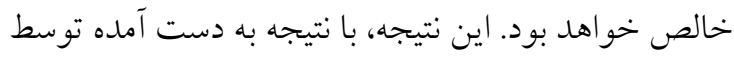
مقدا و عبدالرحمان ( Magda and Abd EL-Rahman, 2013) مغايرت دارد. به طور كلى نتايج متفاوت در

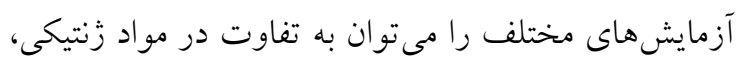
اندازه نمونه و محيط آزمايش نسبت داد.

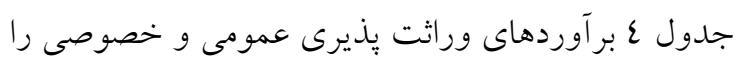
نشان مى دهد. وراثت يذيرى عمومى و خصوصى در اكثر صفات مورد مطالعه به ترتيب نسبتا بالا و نسبتا هايين بودند.در دو شرايط عادى و تنش كمبود آب تعداد ينجه 
جدول ا- ميانخين صفات مختلف در نسل هاى مورد مطالعه در متوسط دو شرايط عادى و تنش كمبود آب

Table 1. Means of different traits for the studied generations under normal and water deficit conditions

\begin{tabular}{|c|c|c|c|c|c|c|c|c|c|c|c|c|}
\hline $\begin{array}{c}\text { نسل } \\
\text { Generation }\end{array}$ & $\begin{array}{c}\text { ارتفاع بوته } \\
\text { PH } \\
\text { (cm) }\end{array}$ & $\begin{array}{c}\text { طول يدانكل } \\
\text { PL } \\
\text { (cm) }\end{array}$ & $\begin{array}{c}\text { طول برگ يرجم } \\
\text { FLL } \\
\text { (cm) }\end{array}$ & 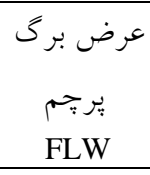 & تعداد ينجه & كلروفيل & $\begin{array}{c}\text { دماى برى } \\
\text { LT } \\
\left(c^{\circ}\right)\end{array}$ & تعداد روز تا & $\begin{array}{c}\text { وزن سنبله } \\
\text { HW } \\
\left(\mathrm{kg} \mathrm{ha}^{-1}\right)\end{array}$ & $\begin{array}{c}\text { وزن كاه } \\
\text { STW } \\
\left(\mathrm{kg} \mathrm{ha}^{-1}\right)\end{array}$ & $\begin{array}{c}\text { بيوماس } \\
\text { Bio } \\
\left(\mathrm{kg} \mathrm{ha}^{-1}\right)\end{array}$ & $\begin{array}{l}\text { شاخص } \\
\text { HI (\%) } \\
\end{array}$ \\
\hline $\mathrm{P}_{1}$ & 55.450 & 21.892 & 16.942 & 1.484 & 2.367 & 48.242 & 29.562 & 93.750 & 4033.836 & 4281.188 & 8415.024 & 24.480 \\
\hline $\mathrm{P}_{2}$ & 50.992 & 18.218 & 17.867 & 1.143 & 1.631 & 39.056 & 29.865 & 90.000 & 2403.987 & 2597.740 & 5001.727 & 23.569 \\
\hline $\mathrm{F}_{2}$ & 54.722 & 22.605 & 15.028 & 1.297 & 2.490 & 49.719 & 30.109 & 95.438 & 4165.642 & 4528.899 & 8594.541 & 22.885 \\
\hline $\mathrm{RF}_{2}$ & 53.699 & 19.439 & 16.124 & 1.636 & 2.126 & 45.132 & 28.973 & 91.563 & 3293.590 & 2922.071 & 6215.662 & 28.446 \\
\hline $\mathrm{BC}_{1}$ & 58.753 & 20.614 & 18.994 & 1.384 & 2.857 & 47.861 & 29.998 & 94.000 & 4723.119 & 4845.328 & 9568.447 & 23.551 \\
\hline $\mathrm{BC}_{2}$ & 48.837 & 17.492 & 14.841 & 1.269 & 2.050 & 44.862 & 31.317 & 89.750 & 3216.479 & 2340.598 & 5557.077 & 31.824 \\
\hline LSD (\%5) & 5.414 & 2.406 & 1.921 & 0.193 & 0.692 & 4.029 & 0.834 & 3.189 & 1223.001 & 1031.999 & 2131.011 & 4.014 \\
\hline
\end{tabular}

PH: Plant height, PL: Peduncle length, FLL: Flag leaf length, FLW: Flag leaf width, ETN: Effective tiller number, Chl: Chlorophyll content, LT: Leaf temperature, DM: Days to maturity, HW: Head weight, STW: Straw weight, Bio: Biomass, HI; Harvest index.

جدول r- ميانگين عملكرد دانه در واحد سطح (kg ha (kg در نسلهاى مورد مطالعه در هر دو شر ايط نرمال و تنش كمآبى

Table 2. Mean grain yield per hectar for the generations under study in normal and water deficit stress conditions

\begin{tabular}{c}
\hline نeneration \\
Gen
\end{tabular}

\begin{tabular}{ccc} 
Generation & Normal & Water deficit \\
\hline $\mathrm{P}_{1}$ & 2201.94 & 1877.84 \\
$\mathrm{P}_{2}$ & 1460.99 & 982.28 \\
$\mathrm{~F}_{2}$ & 1942.14 & 1449.63 \\
$\mathrm{RF}_{2}$ & 2181.31 & 1307.32 \\
$\mathrm{BC}_{1}$ & 2715.51 & 2220.50 \\
$\mathrm{BC}_{2}$ & 1969.16 & 1396.96 \\
\hline LSD $(\% 5)$ & & 967.5
\end{tabular}

LSD was calculated for the interaction of water regime with generation (for two columns). 
جدول بـ برآورد بارامترهاى زنتيكى در مدل مورد مطالعه تحت شرايط عادى و تنش كم آبى با روش تجزيه ميانخين نسلها

Table 3. Estimation of genetic parameters for the studied models under normal and water deficit stress conditions using generation man analysis

\begin{tabular}{|c|c|c|c|c|c|c|c|c|}
\hline صفات (Traits) & $\begin{array}{c}\text { شرايط آبيارى } \\
\text { (Irrigation condition) }\end{array}$ & $\mathrm{m}$ & [d] & {$[\mathrm{h}]$} & aa [i] & ad [j] & dd [1] & $x^{2}$ \\
\hline \multirow{2}{*}{ ارتفاع بوته (PH) } & نرمال (Normal) & $66.78^{* * * *} \pm 5.956$ & $4.01^{* * * *} \pm 1.101$ & $-48.13^{* * *} \pm 4.034$ & $-12.11^{*} \pm 5.892$ & - & $88.30^{* * * *} \pm 11.920$ & $5.87^{\mathrm{ns}}$ \\
\hline & تنش (Water deficit) & $57.028^{* * * * *} \pm 8.818$ & $3.57^{* * * w} \pm 1.077$ & $-50.89^{* * *} \pm 6.874$ & $-3.64^{*} \pm 1.752$ & $11.99^{* * \cdots *} \pm 4.215$ & - & $60.24^{* *}$ \\
\hline \multirow{2}{*}{ طول يدانكل (PL) } & نرمال (Normal) & $26.70^{* * * * \pm} \pm 5.749$ & $2.20^{* * * *} \pm 0.759$ & $11.58^{* * * *} \pm 4.053$ & $-6.43^{\prime \prime} \pm 2.684$ & - & $-55.20^{* * * *} \pm 11.751$ & $0.48^{\text {ns }}$ \\
\hline & تنش (Water deficit) & $26.14^{* \cdots *} \pm 4.777$ & $2.15^{* * *} \pm 0.719$ & $-16.59^{* * * *} \pm 6.243$ & $-6.90^{* * *} \pm 2.281$ & - & - & $1.64^{\mathrm{ns}}$ \\
\hline \multirow{2}{*}{ طول برك يرجم (FLL) } & نرمال (Normal) & $17.94^{* * *} \pm 0.621$ & $1.42^{*} \pm 0.431$ & $-45.39^{* * *} \pm 16.549$ & - & - & $82.97^{* * * *} \pm 30.699$ & $0.31^{\text {ns }}$ \\
\hline & تنش (Water deficit) & $16.55^{5 * * *} \pm 3.297$ & $-1.36^{* * *} \pm 0.347$ & $-48.89^{* * *} \pm 3.217$ & $-3.03^{* * *} \pm 1.013$ & - & - & $5.82^{\text {ns }}$ \\
\hline \multirow{2}{*}{ عرض برى يرجّم (FLW) } & نرمال (Normal) & $1.28^{* * * \pm 0.293}$ & $0.19^{* * * *} \pm 0.027$ & $2.81^{* * * *} \pm 1.049$ & $1.03^{* * * \pm} \pm 0.291$ & - & $-5.10^{* \prime} \pm 2.537$ & $0.99^{\text {ns }}$ \\
\hline & تنش (Water deficit) & $1.09^{* * *} \pm 0.233$ & $0.16^{* * *} \pm 0.033$ & $0.82^{* * * *} \pm 0.301$ & $0.35^{* * *} \pm 0.131$ & $-0.29^{\prime \prime} \pm 0.139$ & - & $0.26^{\mathrm{ns}}$ \\
\hline \multirow{2}{*}{ تعداد بِنجه بارور (ETN) } & نرمال (Normal) & $2.39^{* * *} \pm 0.678$ & $0.93^{* * *} \pm 0.211$ & $2.79^{* * *} \pm 1.001$ & $1.72^{* * *} \pm 0.612$ & $0.698^{* * * *} \pm 1.92$ & - & $2.78^{\mathrm{ns}}$ \\
\hline & تنش (Water deficit) & $2.23^{* * *} \pm 0.874$ & $0.68^{* * *} \pm 0.254$ & $-1.90^{* * *} \pm 0.701$ & $-0.42^{* *} \pm 0.102$ & - & - & $3.46^{\mathrm{ns}}$ \\
\hline \multirow{2}{*}{ ميزان كلروفيل (Chl) } & نرمال (Normal) & $50.11^{1 * * *} \pm 7.751$ & $3.93^{* *} \pm 0.851$ & $-18.37^{* * * *} \pm 6.195$ & $-14.75^{* * *} \pm 4.766$ & - & - & $0.35^{\text {ns }}$ \\
\hline & تنش (Water deficit) & $45.55^{5 * \cdots} \pm 4.883$ & $2.19^{* * *} \pm 0.687$ & $148.25^{* * *} \pm 54.777$ & $-3.18^{* * *} \pm 1.167$ & - & $-291.20^{* * *} \pm 82.175$ & $20.65^{* *}$ \\
\hline \multirow{2}{*}{ دماى برى (LT) } & نرمال (Normal) & $28.67^{* * *} \pm 0.411$ & $-1.04^{* * * *} \pm 0.339$ & $51.02^{* * * *} \pm 17.353$ & 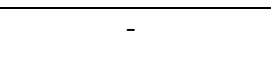 & - & $35.322^{* * * \pm} \pm-101.10$ & $0.04^{\mathrm{ns}}$ \\
\hline & تنش (Water deficit) & $30.69^{* * *} \pm 2.549$ & $-0.87^{\prime \prime} \pm 0.428$ & $85.01^{* * *} \pm 30.729$ & $2.05^{\prime \prime} \pm 1.015$ & - & $57.392^{* * *} \pm-155.50$ & $1.13^{\mathrm{ns}}$ \\
\hline \multirow{2}{*}{$\begin{array}{l}\text { تعداد روز تا رسيدىى } \\
\text { (DM) }\end{array}$} & نرمال (Normal) & $106.58^{* * * \pm} \pm 3.164$ & $4.40^{* * *} \pm 0.421$ & $168.09^{* * " *} \pm 45.609$ & $-13.60^{* * * * \pm} \pm 3.128$ & - & $96.606^{* * * \pm} \pm-375.00$ & $0.01^{\mathrm{ns}}$ \\
\hline & تنش (Water deficit) & $93.91^{* * * *} \pm 2.782$ & $0.69^{* * *} \pm 0.249$ & $-3.56^{* * *} \pm 1.107$ & $-3.32^{* * *} \pm 1.214$ & - & - & $0.15^{\mathrm{ns}}$ \\
\hline \multirow{2}{*}{ وزن سنبله (HW) } & نرمال (Normal) & $316.228^{* * * *} \pm 3786.30$ & $316.228^{* * *} \pm 883.60$ & $605.634^{* * * \pm} \pm-1720.52$ & - & - & $6014.93^{* * * \pm 2076.256}$ & $249.65^{* *}$ \\
\hline & تنش (Water deficit) & $1021.292^{* * "} \pm 3320.44$ & $325.669^{* * * *} \pm 873.25$ & $469.523^{* * *} \pm 1967.57$ & $154.997^{* * * \pm 430.99}$ & - & - & $207.28^{* *}$ \\
\hline \multirow{2}{*}{ وزن كاه (STW) } & ن نرمال (Normal) & $366.947^{* * * *} \pm 4640.02$ & $301.242^{* * * *} \pm 976.59$ & $201.754^{* * * \pm} \pm-1027.23$ & $78.254^{* * \cdots} \pm-272.65$ & - & $136.94^{* * * *} \pm 48.585$ & $59.68^{* *}$ \\
\hline & تنش (Water deficit) & $1004.315^{* * "} \pm 3338.86$ & $199.743^{* * *} \pm 582.89$ & $208.317^{7 * * *} \pm 1167.02$ & $102.551^{* * *} \pm-278.63$ & - & & $113.26^{* *}$ \\
\hline
\end{tabular}




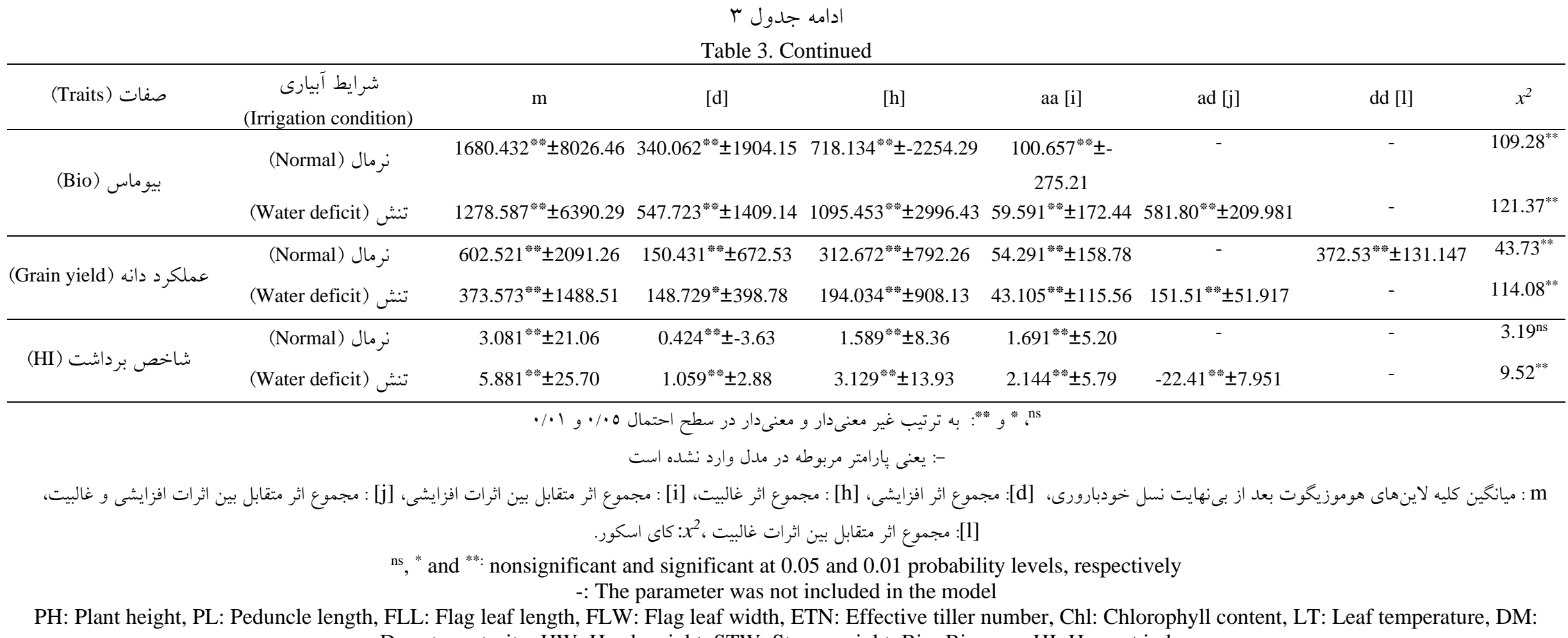
Days to maturity, HW: Head weight, STW: Straw weight, Bio: Biomass, HI; Harvest index 
جدول ع- برآورد واريانس هاى زنتيكى، وراثتيذيرى عمومى، وراثتيذيرى خصوصى و متوسط غالبيت در صفات مورد مطالعه تحت دو شر ايط عادى و تنش كم آبى با استفاده از نسل هاى مختلف

Table 4. Estimates of genetic variances, broad sense and narrow sense heritabilility and average degree of dominance for the studied traits under normal and water deficit

\begin{tabular}{|c|c|c|c|c|c|c|c|c|c|}
\hline \multicolumn{10}{|c|}{ fferent generations } \\
\hline صفات (Traits) & $\begin{array}{c}\text { شرايط ابيارى } \\
\text { (Irrigation condition) }\end{array}$ & A & $\mathrm{D}$ & $\mathrm{V}_{\mathrm{A}}$ & $\mathrm{V}_{\mathrm{D}}$ & $\mathrm{h}^{2}{ }_{\mathrm{bs}}$ & $\mathrm{h}^{2}{ }_{\mathrm{ns}}$ & $\mathrm{V}_{\mathrm{E}}$ & $\overline{\mathrm{a}}$ \\
\hline \multirow{2}{*}{ ارتفاع بو ته (PH) } & نرمال (Normal) & 89.20 & 190.09 & 44.63 & 47.52 & 0.78 & 0.39 & 47.08 & 1.46 \\
\hline & تنش (Water deficit) & 56.57 & 178.21 & 28.29 & 44.55 & 0.78 & 0.30 & 41.96 & 1.78 \\
\hline \multirow{2}{*}{ طول بدانكل (PL) } & نرمال (Normal) & 22.90 & 49.70 & 11.45 & 12.42 & 0.68 & 0.33 & 22.13 & 1.47 \\
\hline & تنش (Water deficit) & 15.28 & 75.82 & 7.64 & 18.96 & 0.77 & 0.22 & 15.82 & 2.23 \\
\hline \multirow{2}{*}{ طول برى يرجم (FLL) } & نرمال (Normal) & 13.90 & 29.73 & 6.95 & 7.43 & 0.78 & 0.38 & 8.18 & 1.46 \\
\hline & تنش (Water deficit) & 12.82 & 30.76 & 6.41 & 7.69 & 0.83 & 0.38 & 5.84 & 1.55 \\
\hline \multirow{2}{*}{ عرض برى ير تجم (FLW) } & نرمال (Normal) & 4.00 & 10.54 & 2.00 & 2.63 & 0.92 & 0.40 & 0.82 & 1.62 \\
\hline & تنش (Water deficit) & 3.13 & 13.60 & 1.56 & 3.40 & 0.93 & 0.29 & 0.73 & 2.09 \\
\hline \multirow{2}{*}{ تعداد بِنجه بارور (ETN) } & نرمال (Normal) & 6.99 & 18.26 & 3.50 & 4.56 & 0.95 & 0.41 & 0.92 & 1.62 \\
\hline & تنش (Water deficit) & 5.13 & 20.24 & 2.57 & 5.06 & 0.95 & 0.32 & 0.79 & 1.99 \\
\hline \multirow{2}{*}{ ميزان كلروفيل (Chl) } & نرمال (Normal) & 34.33 & 94.31 & 17.16 & 23.58 & 0.82 & 0.346 & 17.61 & 1.66 \\
\hline & تنش (Water deficit) & 30.01 & 110.96 & 15.00 & 27.74 & 0.75 & 0.265 & 27.82 & 1.92 \\
\hline \multirow{2}{*}{ دماى برى (LT) } & نرمال (Normal) & 6.83 & 19.57 & 3.42 & 4.89 & 0.79 & 0.33 & 4.36 & 1.69 \\
\hline & تنش (Water deficit) & 8.12 & 22.38 & 4.06 & 5.60 & 0.79 & 0.33 & 5.08 & 1.66 \\
\hline \multirow{2}{*}{ تعداد روز تا رسيدگى (DM) } & نرمال (Normal) & 12.40 & 28.99 & 6.20 & 7.25 & 0.93 & 0.43 & 2.035 & 1.53 \\
\hline & تنش (Water deficit) & 7.02 & 17.87 & 3.51 & 4.47 & 0.82 & 0.36 & 3.413 & 1.60 \\
\hline \multirow{2}{*}{ وزن سنبله (HW) } & نرمال (Normal) & 10049383.19 & 21041178.13 & 5024691.60 & 5260294.53 & 0.82 & 0.40 & 4423562.24 & 1.45 \\
\hline & تنش (Water deficit) & 9528640.06 & 28448378.70 & 4764320.03 & 7112094.68 & 0.88 & 0.35 & 3385956.68 & 1.73 \\
\hline \multirow{2}{*}{ وزن كاه (STW) } & نرمال (Normal) & 1474865.05 & 3130446.98 & 737432.53 & 782611.75 & 0.50 & 0.24 & 3011444.94 & 1.46 \\
\hline & تنش (Water deficit) & 1198723.34 & 4402880.16 & 599361.67 & 1100720.04 & 0.73 & 0.26 & 1255157.23 & 1.92 \\
\hline
\end{tabular}


إدامه جدول

Table 4. Continued

\begin{tabular}{|c|c|c|c|c|c|c|c|c|c|}
\hline صفات (Traits) & $\begin{array}{c}\text { شرايط آبيارى } \\
\text { (Irrigation condition) }\end{array}$ & A & $\mathrm{D}$ & $\mathrm{V}_{\mathrm{A}}$ & $\mathrm{V}_{\mathrm{D}}$ & $\mathrm{h}^{2} \mathrm{bs}$ & $\mathrm{h}^{2}{ }_{\mathrm{ns}}$ & $V_{E}$ & $\overline{\mathrm{a}}$ \\
\hline \multirow{2}{*}{ بيوماس (Bio) } & نرمال (Normal) & 30392477.12 & 60973700.37 & 15196238.56 & 15243425.09 & 0.80 & 0.40 & 15560563.48 & 1.42 \\
\hline & تنش (Water deficit) & 2811630.99 & 74756081.87 & 14058154.49 & 18689020.47 & 0.87 & 0.37 & 9640868.97 & 1.63 \\
\hline \multirow{2}{*}{$\begin{array}{c}\text { Grain ) عملكرد دانه } \\
\text { (yield }\end{array}$} & نرمال (Normal) & 5956538.83 & 13228776.89 & 2978269.41 & 3307194.22 & 0.63 & 0.30 & 7423562.24 & 1.49 \\
\hline & تنش (Water deficit) & 3738579.76 & 14010621.25 & 1869289.88 & 3502655.31 & 0.65 & 0.23 & 5704254.72 & 1.94 \\
\hline \multirow{2}{*}{ شاخص برداشت (HI) } & نرمال (Normal) & 128.32 & 296.11 & 64.16 & 74.03 & 0.90 & 0.42 & 30.39 & 1.52 \\
\hline & تنش (Water deficit) & 95.80 & 473.33 & 47.90 & 118.33 & 0.90 & 0.26 & 36.79 & 2.22 \\
\hline
\end{tabular}

$\mathrm{A}, \mathrm{D}, \mathrm{V}_{\mathrm{A}}, \mathrm{V}_{\mathrm{D}}, \mathrm{h}_{\mathrm{bs}}^{2}, \mathrm{~h}_{\mathrm{ns}}^{2}, \mathrm{~V}_{\mathrm{E}}, \overline{\mathrm{a}}$ : Additive variance component, Dominance variance component, Additive variance, Dominance variance, Broad sense hertablility, Narrow sense hertablility, Average degree of dominance, respectively.

PH: Plant height, PL: Peduncle length, FLL: Flag leaf length, FLW: Flag leaf width, ETN: Effective tiller number, Chl: Chlorophyll content, LT: Leaf temperature, DM: Days to maturity, HW: Head weight, STW: Straw weight, Bio: Biomass, HI; Harvest index. 
هيبريد گندم در حال حاضر در سطح محدودى در كشور

هاى امريكا، فرانسه، استراليا و آفريقاى جنوبى به طور

تجارى توليد مىشوند (Edwards 2001). در عين حال به تركئ

علت برترى واريته هاى هيبريد گندم نسبت به لاينهاى

خالص از نظر عملكرد و وِيايدارى همماكنون برنامههاى

تحقيق و توسعه فعالى در خصوص گندم هيبريد در بيش

از 17 كشور در دنيا از جمله جين، زاين، هندوستان،

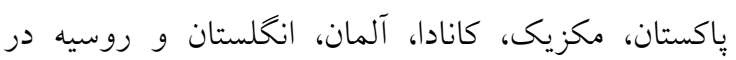

جريان است (Singh et al., 2010) و برخى از موسسات

و شركتهاى بزرگ اعلام كردهاند كه (Ledbetter, 2016)

واريتههاى هيبريد گندم را در عرض جند سال آينده به بازار

$$
\text { عرضه خواهند كرد. }
$$

$$
\begin{aligned}
& \text { به طور كلى مجموعه تجزيه ميانخين نسلها و تجزيه } \\
& \text { واريانس نسلها نشان دادند كه در هر دو شرايط عادى و } \\
& \text { تنش كمبود آب اثرهاى إييستازى و غالبيت علاوه بر اثر } \\
& \text { افزايشى در كنترل صفات زراعى مورد مطالعه از جمله } \\
& \text { عملكرد دانه نقش دارند. اين امر لزوم توليد واريتههاى }
\end{aligned}
$$

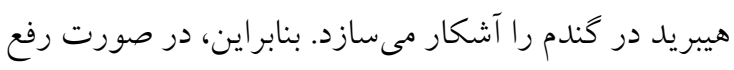

$$
\begin{aligned}
& \text { مشكلات ايجاد نرعقيمى و انتقال گرده در اين گياه توليد } \\
& \text { واريته هاى هيبريد موجب افزايش عملكرد خواهد شد. } \\
& \text { آزمايشها نشان دادهاند كه زَنوتيبٍ هاى هيبريد گندم نسبت } \\
& \text { به ارقام خالص از نظر عملكرد دانه و عملكرد كاه بهتر } \\
& \text { بوده و در شرايط دشوار محيطى از يايدارى عملكرد بيشترى } \\
& \text { برخوردار هستند (Longin et al., 2012). واريتههاى }
\end{aligned}
$$

\section{References}

Abedi, J., Baghizadeh, A. and Mohammadi-Nejad, G. (2015). Genetic analysis for some morphological traits in bread wheat under drought stress condition using generations mean analysis. Journal of Stress Physiology and Biochemistry, 11(2): 40-48.

Akhtar, N. and Chowdhry, M.A. (2006). Genetic analysis of yield and some other quantitative traits in bread wheat. International Journal of Agriculture and Biology, 4: 523-527.

Amawate, J.S. and Behl, P.N. (1995). Genetic analysis of some quantitative components of yield in bread wheat. Indian Journal of Genetics and Plant Breeding, 55: 120-125.

Anonymous (2013). Identification and releasing of new wheat and barley cultivars adapted to drought prone environments. South Khorasan Agricultural and Natural Resources Research and Training Center (In Persian).

Asadi, A.A., Valizadeh, M., Mohammadi, S.A. and Khodarahmi, M. (2015). Genetic analysis of some physiological traits in wheat by generations mean analysis under normal and water deficit conditions. Biological Forum, 7: 722-733.

Bilgin, O., Kutlu, I and Balkan, A. (2016). Gene effects on yield and quality traits in two bread wheat (T. aestivum L.) crosses. International Journal of Crop Science and Technology, 2: 1-10.

Blum, A. (1988). Plant Breeding for Stress Environments. CRC Press, Boca Raton. USA.

Cheloei, GH.R., Mohammadi, A., Bihamta, M.R., Ramshini, H.A. and Najafian, G. (2012). Inheritance of drought tolerance in bread wheat using generation mean analysis. Journal of Plant Production, 19(1): 43-66.

Chowdhry, M.A., Rasool, I., Khaliq, I., Mahmood, T. and Gilani, M.M. (1999). Genetics of some metric traits in spring wheat under normal and drought environment. Rachis Newsletter, 18: 34-39.

Daryanto, S., Wang, L. and Jacinthe, P.A. (2016). Global Synthesis of Drought Effects on Maize and Wheat Production. PLOS ONE 11(5): e0156362. https://doi.org/10.1371/journal.pone.0156362.

Edwards, I.B. (2001). Hybrid wheat. In: Bonjean, A.P. and Angus, W.J. (Eds.). The World Wheat Book, A History of Wheat Breeding, pp. 1017-1045. Lavoisier Inc., Paris.

Edvards, L., Ketata, H. and Smith, E.L. (1976). Gene action of heading date, plant height and other characters in two winter wheat crosses. Crop Science, 16: 275-279.

Erkul, A., Unay, A. and Konak, C. (2010). Inheritance of yield and yield components in a bread wheat (Triticum aestivum L.) cross. Turkish Journal of Field Crops, 15: 137-140. 
Eshghi, R., Ojaghi, J., Rahimi, M. and Salayeva, S. (2010). Genetic characteristics of grain yield and its components in barley (Hordeum vulgare L.) under normal and drought conditions. Journal of Agriculture and Environmental Sciences, 9: 519-528.

Gamble, P.E. and Burke, J.J. (1984). Effect of water stress on the chloroplast antioxidant system. Alterations in glutathione reductase activity. Plant Physiology, 76: 615-621.

Guo, X.Y., Zhang, X.S. and Huang, Z.Y. (2010). Drought tolerance in three hybrid poplar clones submitted to different watering regimes. Journal of Plant Ecology, 3(2): 79-87.

James, R.A., Rivelli, A.R., Munns, R. and Caemmerer, S.V. (2002). Factors affecting $\mathrm{CO}_{2}$ assimilation, leaf injury and growth in salt-stressed durum wheat. Functional Plant Biology, 29: 1393-1403.

Khattab, S.A.M., Esmail, R.M. and Abd EL-Rahman, M.F. (2010). Genetical analysis of some quantitative traits in bread wheat (Triticum aestivum L.). New York Science Journal, 3(11): 152-157.

Koocheki, A.R., Yazdansepas, A., Mahmadyorov, U. and Mehrvar, M.R. (2014). Physiologicalbased selection criteria for terminal drought in wheat (Triticum aestivum L.). Journal of Agricultural Science and Technology, 16: 1043-1053.

Ledbetter, K. (2016). Hybrid wheat time has come. AgriLife Research, Department of Soil and Crop Sciences, College of Agriculture and Life Sciences, Texas A\&M University, Texas, USA. https://today.agrilife.org/2016/02/25/hybrid-wheat-time-has-come/

Longin, C.F.H., Mühleisen, J., Maurer, H.P., Zhang, H., Gowda, M. and Reif, J.C. (2012). Hybrid breeding in autogamous cereals. Theoretical and Applied Genetics, 125: 1087-1096.

Magda, E. and Abd EL-Rahman, M.F. (2013). Estimation of some genetic parameters through generation mean analysis in three bread wheat crosses. Alexandria Journal of Agricultural Research, 58(3): 183-195.

Mather, K. and Jinks, J.L. (1982). Biometrical Genetics. The Study of Continuous Variation. Chapman and Hall, USA. pp 279.

Moemeni, A., Afuni, D. and Zarei, G. (2008). Comparison of yield and genetic features of some advanced lines of wheat under late season drought. Journal of Crop Sciences, 5: 63-71.

Mohamed, N. (2014). Genetic control for some traits using generation mean analysis in bread wheat (Triticum aestivum L.). International Journal of Plant and Soil Science, 3(9): 1055-1068.

Mohammadi, R., Armion, M., Kahrizi, D. and Amri, A. (2010). Efficiency of screening techniques for evaluating durum wheat genotypes under mild drought conditions. International Journal of Plant Production, 4: 11-24.

Muller, J. (1991). Determining leaf surface area by means of a wheat osmoregulation water use: the challenge. Agriculture Meteorology, 14: 311-320.

Munir, M., Chowdhry, M.A. and Malik, T.A. (2007). Correlation studies among yield and its components in bread wheat under drought conditions. International Journal of Agriculture and Biology, 9(2): 287-290.

Passioura, J.B. (2007). The drought environment: Physical, biological and agricultural perspectives. Journal of Experimental Botany, 58: 113-117.

Prakash, V., Saini, D.D. and Pancholi, S.R. (2006). Genetic basis of heterosis for grain yield and its traits in wheat under normal and late sown conditions. Crop Research, 31(2): 245-253.

Roy, D. (2000). Plant Breeding (Analysis and Exploitation of Variation). Alpha Science International Ltd, U.K.

Sheikh, S., Singh, I. and Singh, J. (2000). Inheritance of some quantitative traits in bread wheat (Triticum aestivum L.). Annals of Agricultural Research, 21: 51-54.

Singh, R.P. and Sing, S. (1992). Estimation of genetic parameters through generation mean analysis in bread wheat. Indian Journal of Genetics and Plant Breeding, 52: 369-375.

Singh, S.K., Chatrath, R. and Mishra, B. (2010). Perspective of hybrid wheat research: A review. Indian Journal of Agricultural Sciences, 80 (12): 1013-1027. 


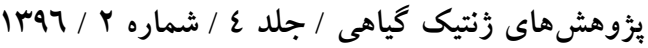

Sultan, M.S., Abd El-Latif, A.H., Abd El-Moneam, M.A. and El-Hawary, M.N.A. (2011). Genetic parameters for some yield and yield components characters in four cross of bread wheat under two water regime treatments. Journal of Plant Production, 2: 351-366.

Uddin, F., Mohammad, F. and Ahmed, S. (2015). Genetic divergence in wheat recombinant inbred lines for yield and yield components. American-Eurasian Journal of Agricultural and Environmental Sciences, 15(9): 1854-1859. 


\title{
Inheritance of Agronomical and Physiological Traits in the Progeny of Moghan3 and Arg Bread Wheat Varieties Cross
}

\author{
Soheila Shayan", Mohammad Moghaddam Vahed ${ }^{2, *}$, Majid Norouzi ${ }^{3}$, \\ Seyed Abolghasem Mohammadi' ${ }^{2}$, Mahmoud Toorchi ${ }^{2}$ and Bafrin Molaei ${ }^{4}$ \\ 1- Ph.D. Student, Department of Plant Breeding and Biotechnology, University of Tabriz, \\ Tabriz, Iran \\ 2- Professor, Department of Plant Breeding and Biotechnology, University of Tabriz, Tabriz, \\ Iran \\ 3- Associate Professor, Department of Plant Breeding and Biotechnology, University of \\ Tabriz, Tabriz, Iran \\ 4- Former M.Sc. Student, Department of Plant Breeding and Biotechnology, University of \\ Tabriz, Tabriz, Iran
}

(Received: February 7, 2017 - Accepted: August 30, 2017)

\begin{abstract}
Drought stress is one of the factors that reduces yield in the world. Considering that wheat is grown mostly in semi-arid areas, much attention has been paid to develop drought tolerant varieties. This experiment was conducted during 2013-2014 in Tabriz University research farm, Iran. In this investigation the inheritance of some agronomic and physiological traits was studied in the field condition through generations mean analysis. The generations were produced from the cross of Arg (tolerant to drought) and Moghan3 (sensitive to drought) varieties. The experiment was a split plot design based on randomized complete blocks with two replications. The irrigation conditions were arranged in the main plots and generations in the subplots. In the stress condition, irrigation was withheld after pollination. Based on the analysis of variance, significant difference were observed among different generations in terms of plant height, peduncle length, flag leaf length, flag leaf width, number of fertile tillers, leaf chlorophyll content, leaf temperature, days to maturity, spike weight, straw weight, biomass, grain yield and harvest index. The interaction between generations and irrigation conditions was significant only for grain yield. The generation mean analysis in both normal and drought stress conditions showed that chi-square of three parameter model was significant for all of the studied characteristics, indicating the presence of non-allelic interactions in the inheritance of these traits. The broad sense and narrow sense heritabilities for the traits under study were estimated as 0.502-0.946 and 0.244-0.429 in the normal condition and 0.653-0.951 and 0.221-0.377 in the water stress condition, respectively. The average degree of dominance for all of the characters in both normal and water stress conditions was greater than one which indicated the existence of over-dominance gene action in controlling these traits. At both conditions, the dominance genetic variance was higher than the additive genetic variance for all of the traits. The results indicate the necessity of selection in advanced generation or exploiting dominance gene action in the breeding programs, if hybrid varieties are produced in the wheat plant.
\end{abstract}

Keywords: Drought stress, Generation mean analysis, Heritability, Wheat

\footnotetext{
* Corresponding Author, E-mail: mmoghaddam@tabrizu.ac.ir
} 